\title{
Effect of Environment Upon the Melting Point of $\mathrm{Al}_{2} \mathrm{O}_{3}$
}

\author{
S. J. Schneider and C. L. McDaniel
}

\author{
Institute for Materials Research, National Bureau of Standards, Washington, D.C. 20234
}

(April 24, 1967)

\begin{abstract}
The melting point of $\mathrm{Al}_{2} \mathrm{O}_{3}$ has been determined in vacuum, air, argon, and helium utilizing iridium or tungsten containers. All melting point experiments were conducted in induction furnaces capable of heating small samples under blackbody conditions to $3000{ }^{\circ} \mathrm{C}$ in vacuum, $2600{ }^{\circ} \mathrm{C}$ in inert atmospheres, and $2400{ }^{\circ} \mathrm{C}$ in air. Temperatures were continuously monitored with a recording photoelectric pyrometer which has a sensitivity of $\pm 0.2^{\circ}$ at $1063{ }^{\circ} \mathrm{C}$ and $\pm 1^{\circ}$ at $2000{ }^{\circ} \mathrm{C}$. Melting points were determined on specimens having a purity in excess of 99.9 percent. The data indicated that the melting point of $\mathrm{Al}_{2} 0_{3}$ determined in vacuum $\left(\sim 6.5 \times 10^{-5}\right.$ torr $)$ is $2051{ }^{\circ} \mathrm{C}$ (IPTS). The overall maximum uncertainty was estimated to be $\pm 6{ }^{\circ} \mathrm{C}$. The measurements themselves were precise within $\pm 1.5^{\circ} \mathrm{C}$. Vacuum treatment had least detrimental effect upon the $\mathrm{Al}_{2} \mathrm{O}_{3}$ specimens. Each of the gaseous atmospheres including air yielded lower melting points for $\mathrm{Al}_{2} 0_{3}$, presumably due to a premelting phenomenon.
\end{abstract}

Key Words: $\mathrm{Al}_{2} 0_{3}$, dissociation, environmental effects, melting point, premelting.

\section{Introduction}

The International Practical Temperature Scale of 1948 (IPTS) [1] ${ }^{1}$ represents an experimental approach to the ideal thermodynamic temperature scale. Six points define the practical scale between the lowest assigned value, the oxygen point $\left(-182.97{ }^{\circ} \mathrm{C}\right)$ and the highest, the gold point $\left(1063{ }^{\circ} \mathrm{C}\right)^{2}$. Above the gold point, temperatures are based entirely upon the Planck relationship:

$$
\frac{J_{t}}{J_{A u}}=\frac{\exp \left[\frac{C_{\cdot 2}}{\lambda\left(t_{A u}+T_{0}\right)}\right]-1}{\exp \left[\frac{C_{2}}{\lambda\left(t+T_{0}\right)}\right]-1}
$$

where,

$$
\begin{aligned}
J_{A u} \text { and } J_{t}= & \text { radiant energies per unit wavelength } \\
& \text { emitted by unit area of a blackbody } \\
& \text { at temperature } t \text { and the gold point } \\
& t_{A u}\left(1063^{\circ} \mathrm{C}\right) \\
\lambda= & \text { wavelength } \\
C_{2}= & \text { second radiation constant } \\
& \text { cm deg) } \\
T_{0}= & 273.15 \text { deg. }
\end{aligned}
$$

The utilization of the Planck expression to realize the scale above the gold point presents an ideal situation on one hand and a dilemma on the other. Once

\footnotetext{
${ }^{1}$ Figures in brackets indicate the literature references at the end of this paper.
${ }^{2}$ It is anticipated that the numerical value of some of these fixed points and defining constants will be changed in the near future.
}

the gold point and the second radiation constant are defined and the wavelength established, no other material property need be considered. In practice, however, an estimate must be made on how well a temperature measuring system reproduces the IPTS. Generally, this estimate is obtained through calibration against well-defined transformations similar to the fixed points listed for the low and moderate temperature portions of IPTS. The need for additional references is partly met by IPTS which recommends certain secondary points useful for calibration purposes. Table 1 lists the available secondary reference points for temperatures above $1063{ }^{\circ} \mathrm{C}$. Unfortunately, the materials included in the table are few in number and generally not well-suited to a wide variety of applications. All are metals and susceptible to varying degrees of oxidation. Each is specified as applicable to equilibrium conditions under a pressure of one standard atmosphere even though the original data may have been obtained in different environmental situations. The melting points of nickel [2] and rhodium [3] for instance, were determined in a vacuum of 0.01 to $0.001 \mathrm{~mm} \mathrm{Hg}$ while both platinum [4] and iridium [5] were investigated in air. Small variations in pressure generally have inconsequential effect upon a melting point. The chemical nature of the pressure medium, however, cannot be overlooked. Reaction between the environmental gas and the metal standard and container materials could alter the determined melting point significantly.

The lack of recognized high temperature reference materials necessarily has forced the use of pseudo- 
TABLE 1. Secondary reference points of the International Practical Temperature Scale [1]

\begin{tabular}{l|c}
\hline Material & Temperature ${ }^{\text {a }}$ \\
\hline & ${ }^{\circ}$ C, IPTS \\
Copper & b 1083 \\
Nickel & 1453 \\
Cobalt & 1492 \\
Palladium & 1552 \\
Platinum & 1769 \\
Rhodium & 1960 \\
Iridium & 2443 \\
Tungsten & 3380 \\
\hline
\end{tabular}

a The temperature indicates the melting point at one standard atmosphere. ${ }^{\mathrm{b}} \mathrm{A}$ reducing atmosphere is required.

standards which often are of nebulous or unknown quality. The metal oxides and their compounds have been utilized extensively for this purpose. At one time or another materials including $\mathrm{Al}_{2} \mathrm{O}_{3}, \mathrm{Cr}_{2} \mathrm{O}_{3}, \mathrm{MgO}$, $\mathrm{NiO}, \mathrm{CaMgSi}_{2} \mathrm{O}_{6}$ (diopside), 15 percent $\mathrm{CaO}: 85$ percent $\mathrm{SiO}_{2}$ and $\mathrm{CaSiO}_{3}$ [6] all have been employed although there is no common consensus as to their exact melting points. Such a myriad of oxide melting point values have been perpetuated through the literature that present day knowledge regarding these pseudostandards is in a state of utter confusion.

In order to help clarify the situation, the National Bureau of Standards has undertaken a program to completely characterize and elucidate more fully the melting behavior of the metal oxides. The initial effort, since published [6], consisted of a complete literature survey of oxide melting points coupled with a critical analysis and general evaluation of individual investigations. The second part of the program involves the experimental determination of the melting points of a number of the more important oxides with sufficient accuracy and precision to justify their use as reliable reference points.

Numerous metal oxides warrant consideration as reference materials, and foremost among these $\alpha$ $\mathrm{Al}_{2} \mathrm{O}_{3}$ (corundum) appears to be one of the more promising substances. In fact, its melting point was included as one of the secondary reference points on practical temperature scales used by many [7] prior to the adoption of the International Temperature Scale of 1927. Even today, $\mathrm{Al}_{2} \mathrm{O}_{3}$ still is employed widely for calibration purposes, and for this reason, it was selected for the first detailed study. The present work reports results obtained in an investigation of the melting characteristics of $\mathrm{Al}_{2} \mathrm{O}_{3}$ in environments of either vacuum, ${ }^{3}$ argon, helium, or air utilizing tungsten or iridium containers. In this study emphasis was placed on two major problem areas of equal importance. First, every effort was made to insure precise temperature measurements of the highest obtainable accuracy compatible with the actual melting point determination. It is one thing to measure temperatures per se and quite another to determine the temperature at which a transformation occurs. The second area receiving detailed attention was the material aspect of the problem. Strictly speaking the melting point of any

${ }^{3}$ Preliminary results on the melting point of $\mathrm{Al}_{2} \mathrm{O}_{3}$ in vacuum have been published [8]. Since that time, the work has been expanded in scope and for completeness of data and unity of thought, portions of the earlier study are included here. material will remain constant for a given confining pressure. However, if the oxide changes in any manner, whether it be by partial dissociation, chemical reaction, or others, its melting point must change. Knowledge of these changes must be obtained before any credibility can be placed in the determined melting point.

\section{Previous Investigations}

Since 1911 there have been at least 24 separate determinations of the melting point of $\mathrm{Al}_{2} \mathrm{O}_{3}$. Some are of only historical interest, others merit consideration as worthwhile. Table 2 summarizes the important details of each study. With few exceptions each investigation employed optical pyrometry to measure temperatures. Curiously enough, none made any serious attempt to study the effect of environmental conditions.

The melting point preferred by many today is that determined by Kanolt in 1914 [9]. The original value, $2050{ }^{\circ} \mathrm{C}$, is employed time and time again as a reference point even though changes in temperature scales require an adjustment in the original to about $2072{ }^{\circ} \mathrm{C}$ (IP'TS) [10]. In light of some of the more recent work it would appear that the suggested correction is somewhat too high and there is no longer any justification in giving reference to Kanolt because of the inherent uncertainties in the adjusted temperature.

\section{Apparatus}

\subsection{Induction Equipment}

\section{a. Vacuum Furnace}

Figure 1 illustrates the essential components of the vacuum induction furnace and associated equipment. The furnace is capable of attaining about $3000{ }^{\circ} \mathrm{C}$ at reduced pressures. Power for induction heating was supplied to the furnace by a $20 \mathrm{~kW}, 450 \mathrm{kHz}$ radio frequency electronic tube generator used in conjunction with a saturable reactor, magnetic amplifier and an adjustable current controlling device. The power control mechanism provided for both manual and automatic operation. In the manual mode, two ten-turn high precision potentiometers allowed current adjustment in small enough increments to produce temperature changes of less then $2{ }^{\circ} \mathrm{C}$. A filter network of 0.1 $\mu \mathrm{F}$ capacitors were used to prevent extraneous emf from interfering with the control circuit or temperature measurement.

The primary load coil, attached to the rf generator by flexible water-cooled leads, was mounted external to the system around a Pyrex glass bell jar. The induction field from the load coil was concentrated in the region of the susceptor by means of a hollow watercooled copper load coil concentrator. The concentrator was doughnut-shaped, having a vertical bore diameter of $0.875 \mathrm{in}$, an outer diameter of $2.8 \mathrm{in}$, a length of 3.0 in and a 0.01 in wide longitudinal slot.

The bell jar, approximately 7.5 in high and 3.75 in maximum diameter enclosed the concentrator and 
TABLE 2. Compilation of the melting points of $\mathrm{Al}_{2} \mathrm{O}_{3}{ }^{\mathrm{a}}$

\begin{tabular}{|c|c|c|c|c|c|c|c|c|c|}
\hline \multirow{2}{*}{ Date } & \multirow{2}{*}{ Investigator } & \multirow{2}{*}{ Purity } & \multirow{2}{*}{ Furnace type } & \multirow{2}{*}{$\begin{array}{l}\text { Temperature } \\
\text { measurement }\end{array}$} & \multirow{2}{*}{ Method } & \multirow{2}{*}{ Environment } & \multirow{2}{*}{$\begin{array}{l}\text { Original temp. } \\
\text { scale }\end{array}$} & \multicolumn{2}{|c|}{ Melting points ${ }^{c}$} \\
\hline & & & & & & & & Original ${ }^{\circ} \mathrm{C}$ & Int. $1948^{\circ} \mathrm{C}$ \\
\hline 1911 & $\begin{array}{l}\text { Ruff \& } \\
\text { Goecke [33] }\end{array}$ & Not stated & $\begin{array}{c}\text { Resistance, } \\
\text { graphite } \\
\text { element }\end{array}$ & Optical pyrometer & $\begin{array}{l}\text { Observation of } \\
\text { specimen during } \\
\text { heating }\end{array}$ & Nitrogen & $\begin{array}{l}\left(\mathrm{C}_{2}=1.48 \mathrm{~cm} \mathrm{deg}\right) \\
\text { Au point }=1071{ }^{\circ} \mathrm{C}\end{array}$ & 2020 & 2044 \\
\hline 1913 & Ruff [34] & Pure & $\begin{array}{c}\text { Resistance, } \\
\text { graphite } \\
\text { element }\end{array}$ & Optical pyrometer & $\begin{array}{l}\text { Observation of } \\
\text { specimen during } \\
\text { heating }\end{array}$ & Not stated & $\begin{array}{l}\mathrm{C}_{2}=1.46 \mathrm{~cm} \mathrm{deg} \\
\mathrm{Pt} \text { point }=1755^{\circ} \mathrm{C}\end{array}$ & 2010 & 2035 \\
\hline 1914 & Kanolt [9] & $\begin{array}{l}\mathrm{Fe}-0.001 \% \\
\mathrm{SiO}_{2}-0.001 \% \\
\mathrm{Chloride}-0.005 \% \\
\text { Sulfate }-0.001 \%\end{array}$ & $\begin{array}{c}\text { Resistance, } \\
\text { graphite } \\
\text { element }\end{array}$ & Optical pyrometer & $\begin{array}{c}\text { Thermal analysis, } \\
\text { heating curves }\end{array}$ & $\begin{array}{l}\text { (A) Vacuum at } \\
2 \mathrm{~mm} \mathrm{Hg} \\
\text { (B) Hydrogen }\end{array}$ & Not stated ${ }^{d}$ & 2050 & 2072 \\
\hline 1914 & $\begin{array}{l}\text { Tiede \& } \\
\quad \text { Birnbrauer [35] }\end{array}$ & Not stated & Arc & Optical pyrometer & $\begin{array}{l}\text { Observation of } \\
\text { specimen during } \\
\text { heating }\end{array}$ & Vacuum & Not stated & 1890 & \\
\hline 1916 & $\begin{array}{l}\text { Ruff \& } \\
\quad \text { Lauschke [36] }\end{array}$ & Pure & $\begin{array}{c}\text { Resistance, } \\
\text { graphite } \\
\text { element }\end{array}$ & Optical pyrometer & $\begin{array}{l}\text { Observation of } \\
\text { specimen during } \\
\text { heating }\end{array}$ & $\begin{array}{l}\text { (A) Air at } \\
7.5 \mathrm{~mm} \mathrm{Hg}\end{array}$ & $\begin{array}{l}\mathrm{C}_{2}=1.437 \mathrm{~cm} \mathrm{deg} \\
\mathrm{Au} \text { point } \\
=1062.4{ }^{\circ} \mathrm{C}\end{array}$ & (A) 2005 & 2005 \\
\hline 1928 & $\begin{array}{l}\text { v. Wartenberg } \\
\text { et al. [43] }\end{array}$ & Pure & Flame, oil-oxygen & Optical pyrometer & $\begin{array}{l}\text { Observation of } \\
\text { specimen during } \\
\text { heating }\end{array}$ & $\begin{array}{l}\text { (B) Air at } \\
7.7 \mathrm{~mm} \mathrm{Hg} \\
\text { Air }\end{array}$ & Int. 1927 & $\begin{array}{r}\text { (B) } 2008 \\
2055\end{array}$ & 2049 \\
\hline 1931 & Bunting [38] & $99.95 \%$ & $\begin{array}{l}\text { Induction, Ir } \\
\text { alloy susceptor }\end{array}$ & Optical pyrometer & $\begin{array}{l}\text { Examination of } \\
\text { specimen after } \\
\text { heating }\end{array}$ & (Air) & Int. 1927 & 2045 & 2038 \\
\hline 1931 & $\begin{array}{l}\text { Weigel \& } \\
\text { Kaysser [39] }\end{array}$ & $\begin{array}{l}\text { Not stated } \\
\text { Two samples A } \\
\text { and B }\end{array}$ & $\begin{array}{c}\text { Resistance, } \\
\text { graphite } \\
\text { element }\end{array}$ & Optical pyrometer & $\begin{array}{l}\text { Observation of } \\
\text { specimen during } \\
\text { heating }\end{array}$ & $\begin{array}{l}\text { (A1) One atm. } \\
\text { nitrogen } \\
\text { (A2) Air } \\
\text { (B1) Reducing } \\
\text { (B2) Air }\end{array}$ & $\begin{array}{l}\mathrm{C}_{2}=1.44 \mathrm{~cm} \mathrm{deg} \\
\text { Au point }=1063^{\circ} \mathrm{C}\end{array}$ & $\begin{array}{r}\text { (A1) } 2007 \\
\text { (A2) } 2010 \\
\text { (B1) } 2001 \\
\text { (B2) } 2005-2010\end{array}$ & $\begin{array}{r}2009 \\
2012 \\
2003 \\
2007-2012\end{array}$ \\
\hline 1943 & $\begin{array}{l}\text { Geller \& } \\
\quad \text { Bunting [40] }\end{array}$ & $99.98 \%$ & Resistance & $\begin{array}{l}\text { Optical } \\
\text { pyrometer }\end{array}$ & $\begin{array}{l}\text { Observation of } \\
\text { specimen during } \\
\text { heating }\end{array}$ & Air & Int. 1927 & 2035 & 2029 \\
\hline 1945 & $\begin{array}{l}\text { Geller \& } \\
\text { Yavorsky } \\
{[41]}\end{array}$ & $\begin{array}{l}\text { Three } \\
\text { samples: } \\
\text { (A) } 0.05 \% \text { soda } \\
\text { (B) } 0.01 \% \\
\text { impurities } \\
\text { (C) }<.07 \% \\
\text { impurities }\end{array}$ & $\begin{array}{l}\text { Resistance, } \\
\mathrm{ThO}_{2}-\mathrm{CeO}_{2} \\
\text { elements }\end{array}$ & $\begin{array}{l}\text { Optical } \\
\text { pyrometer }\end{array}$ & $\begin{array}{l}\text { Observation of } \\
\text { specimen during } \\
\text { heating }\end{array}$ & (Air) & Int. 1927 & $2000-2030$ & $1994-2024$ \\
\hline 1952 & $\begin{array}{l}\text { Lambertson \& } \\
\text { Gunzel [42] }\end{array}$ & $99.9 \%$ & $\begin{array}{l}\text { Resistance, } \\
\text { W element }\end{array}$ & $\begin{array}{l}\text { Optical } \\
\text { pyrometer }\end{array}$ & $\begin{array}{l}\text { Examination of } \\
\text { specimen after } \\
\text { heating }\end{array}$ & Helium & (Int. 1948) & 2034 & 2034 \\
\hline 1956 & $\begin{array}{l}\text { Lang et al. } \\
{[43]}\end{array}$ & $99.9 \%$ & $\begin{array}{l}\text { Resistance, } \\
\text { graphite } \\
\text { element }\end{array}$ & $\begin{array}{l}\text { Optical } \\
\text { pyrometer }\end{array}$ & $\begin{array}{l}\text { Observation of } \\
\text { specimen during } \\
\text { heating }\end{array}$ & Argon & Int. 1948 & 2049 & 2049 \\
\hline 1959 & $\begin{array}{l}\text { Aldred \& } \\
\text { White [44] }\end{array}$ & High purity & Arc-image & $\begin{array}{l}\text { Radiation } \\
\text { pyrometer }\end{array}$ & $\begin{array}{c}\text { Thermal analysis, } \\
\text { heating curves }\end{array}$ & (Air) & (Int. 1948) & 2060 & 2060 \\
\hline 1959 & Mark [45] & Not stated & $\begin{array}{c}\text { Resistance, } \\
\text { graphite } \\
\text { element }\end{array}$ & $\begin{array}{l}\text { Optical } \\
\text { pyrometer }\end{array}$ & $\begin{array}{l}\text { Observation of } \\
\text { specimen during } \\
\text { heating }\end{array}$ & Neutral & (Int. 1948) & 2020 & 2020 \\
\hline 1960 & $\begin{array}{l}\text { Diamond \& } \\
\text { Schneider } \\
\text { [46] }\end{array}$ & $99.9 \%$ & Solar & $\begin{array}{l}\text { Optical } \\
\text { pyrometer }\end{array}$ & $\begin{array}{l}\text { Observation of } \\
\text { specimen during } \\
\text { cooling }\end{array}$ & Air & Int. 1948 & 2025 & 2025 \\
\hline 1961 & $\begin{array}{l}\text { McNally } \\
\text { et al. } \\
\text { [47] }\end{array}$ & Not stated & $\begin{array}{l}\text { Induction, } \\
\text { graphite } \\
\text { susceptor }\end{array}$ & $\begin{array}{l}\text { Optical } \\
\text { pyrometer }\end{array}$ & $\begin{array}{l}\text { Observation of } \\
\text { specimen during } \\
\text { heating }\end{array}$ & $\begin{array}{l}\text { Air, argon, } \\
\text { nitrogen }\end{array}$ & Int. 1948 & 2043 & 2043 \\
\hline 1963 & $\begin{array}{l}\text { Chekhovskoi } \\
\text { \& Petrov } \\
\text { [48] }\end{array}$ & $\begin{array}{l}0.1-0.2 \% \\
\text { impurities }\end{array}$ & $\begin{array}{l}\text { Resistance, } \\
\text { W element }\end{array}$ & $\begin{array}{l}\text { Optical } \\
\text { pyrometer }\end{array}$ & $\begin{array}{l}\text { Thermal analysis, } \\
\text { heating and } \\
\text { cooling curves }\end{array}$ & Argon & Int. 1948 & 2044 & 2044 \\
\hline 1964 & Gutt [49] & Not stated & $\begin{array}{l}\text { Hot wire, } \\
\text { Ir-Ir alloy } \\
\text { element }\end{array}$ & $\begin{array}{c}100 \mathrm{Ir}-60 \mathrm{Ir}: 40 \mathrm{Rh} \\
\text { thermocouple }\end{array}$ & Not stated & Argon & (Int. 1927) & 2070 & 2063 \\
\hline 1964 & Riley [50] & Not stated & $\begin{array}{l}\text { Resistance, } \\
\text { graphite } \\
\text { element }\end{array}$ & $\begin{array}{l}\text { Optical } \\
\text { pyrometer }\end{array}$ & $\begin{array}{l}\text { Observation of } \\
\text { specimen during } \\
\text { heating }\end{array}$ & Argon & Int. 1948 & $\begin{array}{l}\text { (A) } 2045 \\
\text { (B) } 2050 \\
\text { (C) } 2050\end{array}$ & $\begin{array}{l}2045 \\
2050 \\
2050\end{array}$ \\
\hline 1965 & Foex $[51]$ & $99.97 \%$ & Solar & $\begin{array}{l}\text { Optical } \\
\text { pyrometer }\end{array}$ & $\begin{array}{l}\text { Thermal analysis, } \\
\text { cooling curves }\end{array}$ & Air & Int. 1948 & 2042 & 2042 \\
\hline 1965 & $\begin{array}{l}\text { Gitlesen \& } \\
\text { Motzfeldt } \\
{[29]}\end{array}$ & $>99.7 \%$ & $\begin{array}{c}\text { Resistance, } \\
\text { graphite } \\
\text { element }\end{array}$ & $\begin{array}{l}\text { Optical } \\
\text { pyrometer }\end{array}$ & $\begin{array}{l}\text { Thermal analysis, } \\
\text { heating curves. } \\
\text { Also, by obser- } \\
\text { vation of molten } \\
\text { specimen from } \\
\text { orifice }\end{array}$ & $\begin{array}{l}\text { Argon at } \\
400 \text { torr }\end{array}$ & Int. 1948 & 2041 & 204.1 \\
\hline 1966 & $\begin{array}{r}\text { Kantor et } \\
\text { al., [52] }\end{array}$ & $99.99 \%$ & $\begin{array}{c}\text { Resistance, } \\
\text { graphite } \\
\text { element }\end{array}$ & $\begin{array}{l}\text { Optical } \\
\text { pyrometer }\end{array}$ & $\begin{array}{l}\text { Thermal analysis, } \\
\text { heating and } \\
\text { cooling curves }\end{array}$ & Vacuum ${ }^{e}$ & Int. 1948 & 2049.7 & 2049.7 \\
\hline 1966 & Sata [53] & Pure & $\begin{array}{c}\text { Resistance, } \\
\text { graphite } \\
\text { element }\end{array}$ & $\begin{array}{c}100 \mathrm{~W}-74 \mathrm{~W}: 26 \mathrm{Re} \\
\text { thermocouple }\end{array}$ & Thermal analysis & $\begin{array}{l}\text { Argon at } \\
\quad 30 \mathrm{~mm} \mathrm{Hg}\end{array}$ & Int. 1948 & 2037 & 2037 \\
\hline 1966 & $\begin{array}{l}\text { Urbain \& } \\
\text { Rouannet } \\
\text { [54] }\end{array}$ & $\begin{array}{c}\text { Two samples: } \\
\text { A) }<.3 \% \\
\text { impurities } \\
\text { B) }<.02 \% \\
\text { impurities }\end{array}$ & $\begin{array}{c}\text { Resistance, } \\
\text { graphite } \\
\text { element }\end{array}$ & $\begin{array}{l}\text { Optical } \\
\text { pyrometer }\end{array}$ & Thermal analysis & Argon & Int. 1948 & 2047 & 2047 \\
\hline
\end{tabular}

a All phases, numbers, etc. enclosed in parentheses indicate that these items are not directly expressed in quoted reference. Based on information contained in the report the enclosed terms are assumed valid.

bInt $1927=$ The International Temperature Scale 155]: Int $1948=$ The International Practical Temperature Scale of 1948 [1]: $C_{2}=$ Second radiation constant.
${ }^{c}$ Method of conversion of original values to IPTS of 1948 given by Schneider [6]. ${ }^{\mathrm{d}}$ Kanolt did not employ a defined scale. A complete discussion of his work is reported by Schneider [10].

${ }^{e}$ Chemical Abstracts [56] erroneously reports the environment as argon. 

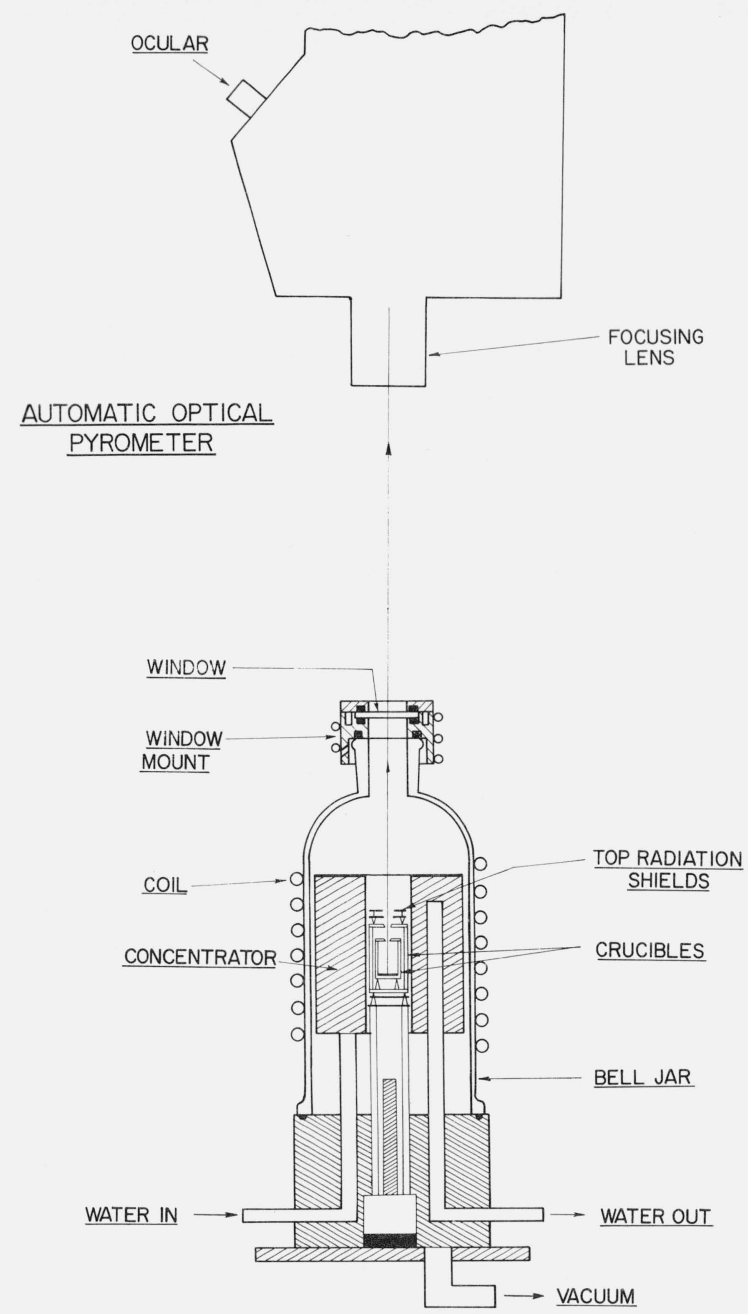

FIGURE 1. Schematic drawing of vacuum induction furnace and related apparatus.

susceptor. The base of the bell jar was located on a brass flange which in turn rested on a brass base plate connected to the vacuum system. A clear 1.125 in diam, 0.125 in thick fused silica window mounted in a water cooled brass holder attached to the top of the bell jar, provided a means to view the interior of the furnace.

High temperature O-rings were employed as vacuum seals between the base plate, flange, bell jar, window mount and window. The vacuum system consisted of a mechanical pump, a 4-in oil diffusion pump and a liquid nitrogen cold trap located between the pumps and the furnace. Pressures were monitored with thermocouple and ion gauges. After degassing, the ultimate obtainable pressure was $1 \times 10^{-6}$ torr. However, at $2000{ }^{\circ} \mathrm{C}$ the normal operating pressure of the system was nominally $6.5 \times 10^{-5}$ torr.

\section{b. Atmosphere Furnace}

Figure 2 indicates the primary features of the equipment used for all work requiring a helium or argon environment. The atmosphere furnace is suitable for use at temperatures up to $2600{ }^{\circ} \mathrm{C}$ at positive pressures of 0 to 50 in $\mathrm{H}_{2} \mathrm{O}$. The environmental setup utilized the same rf generator and control system described for the vacuum furnace. In addition, it was found necessary to incorporate a 12:1 load coil transformer between the generator and the coil. This in essence reduced the potential and increased the amperage of the load coil a sufficient amount to permit heating without apparent ionization of either argon or helium.

The load coil and susceptor were mounted inside a 11 in high, 7 in maximum diameter Pyrex glass bell jar. A plastic retaining collar clamped the bell jar in place and provided a gas tight seal between the aluminum base plate, O-ring and bell jar. The base plate in turn was connected through a valve arrangement to both a mechanical pump and to a gas vent glycerol bubbler. Cold traps were located intermediate between the furnace and the bubbler as well as between the pump and the remainder of the system.

A 1.125 in diam, 0.125 in thick fused silica viewing window mounted in a water-cooled brass holder was attached to the top of the bell jar. Environmental gas was admitted to the system through a 0.125 in diam port located directly below the window. The position of the entrance port aided greatly in preventing severe deposits of condensed vapors from accumulating on the window.

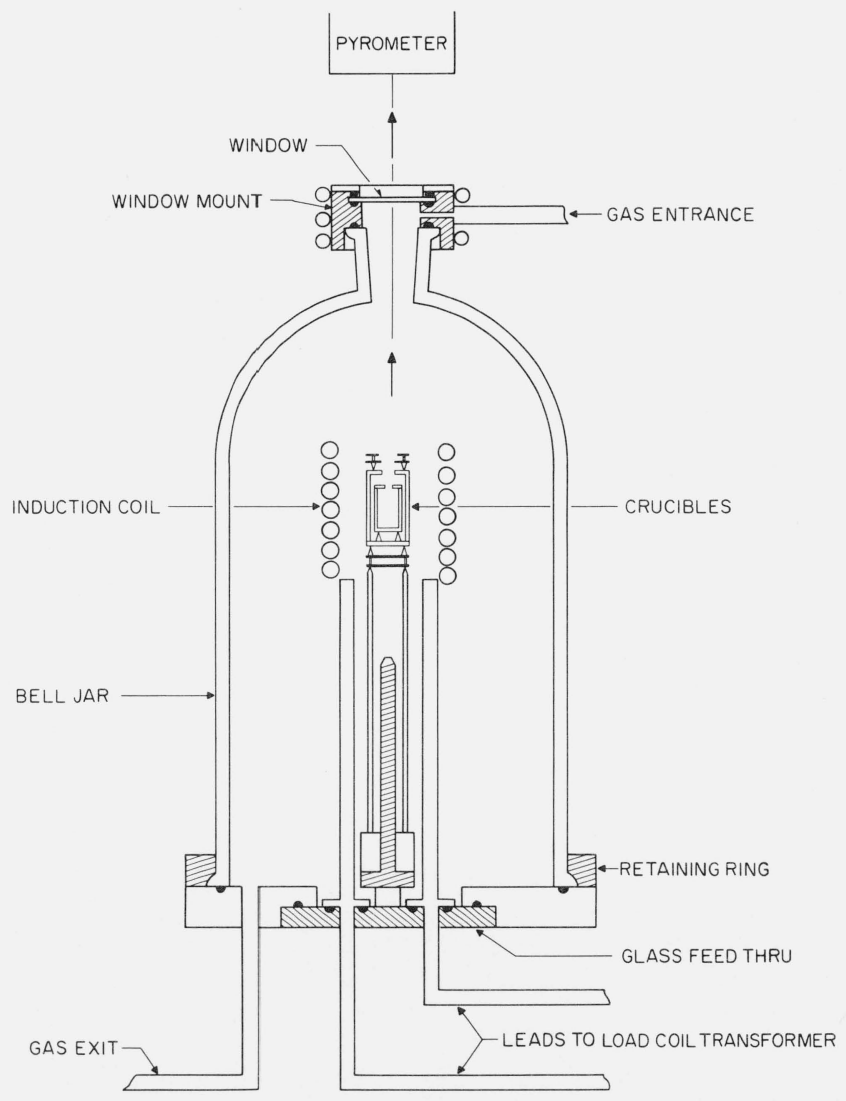

FIGURE 2. Schematic drawing of atmosphere furnace and related apparatus. 


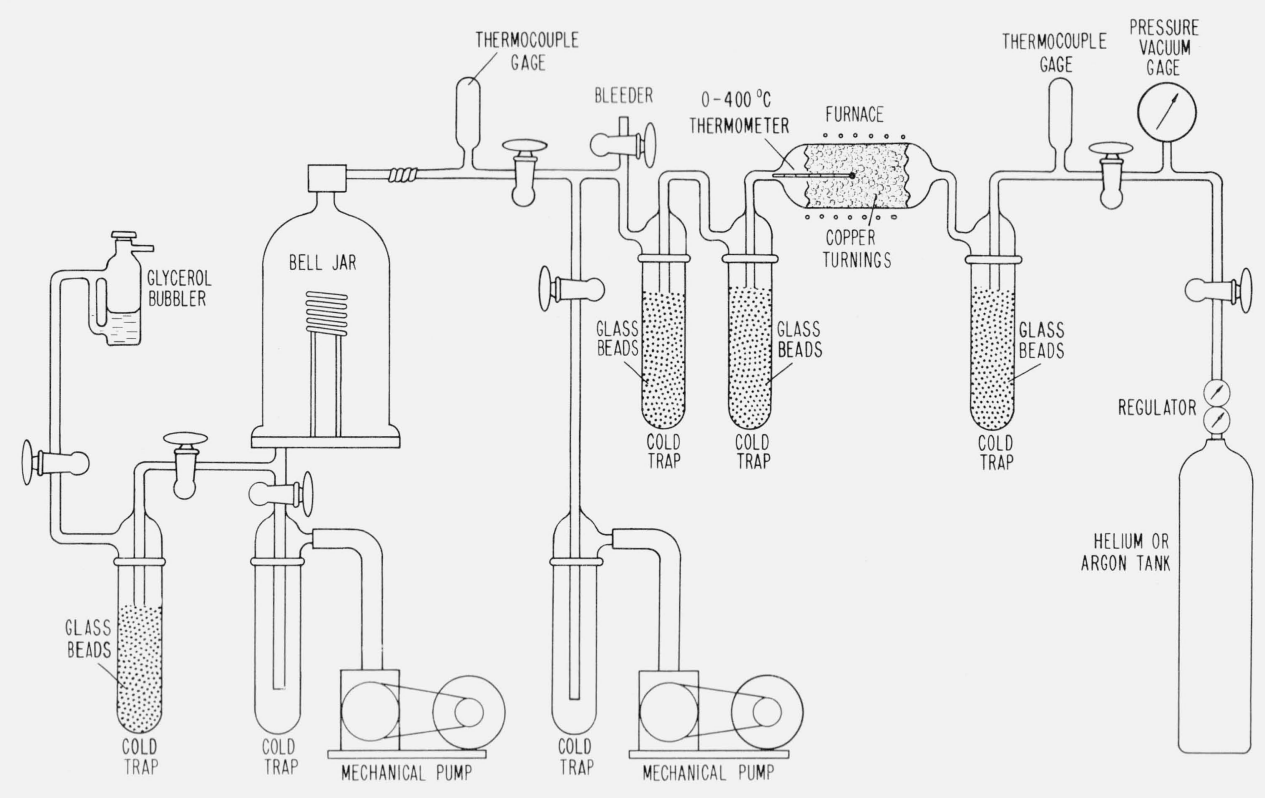

FIGURE 3. Schematic drawing of gas purification train.

Figure 3 shows a schematic diagram of the gas purification train. With the exception of nitrogen, the train regularly can deliver gas to the system having impurity levels less than $10 \mathrm{ppm}$ for helium and $72 \mathrm{ppm}$ for argon. ${ }^{4}$ Gas from the bottled tank passed first through a cold trap, then over hot copper turnings (395 to 400 ${ }^{\circ} \mathrm{C}$ ) and finally through two more cold traps. All three cold traps were filled with glass beads to disperse the flowing gas and promote more efficient trapping of impurities. Liquid nitrogen and an alcohol-dry ice mixture were used as the trap coolants for helium and argon, respectively.

All tubing and connections between the various components of the train were either glass or metal. High diffusion rates through natural or synthetic rubber, plastic or even nylon tubing caused the impurity content of the environmental gas to raise to a sufficiently high level to produce oxidation of the tungsten components of the furnace.

A mechanical pump was used to evacuate the train to facilitate the gas flushing process. Flexible heating tapes aided in degassing the system prior to admitting the environmental gas. Once put into operation the train was never opened to the air. Reduced pressures were determined with thermocouple gauges. A vacuum-pressure $\left(50-0-50\right.$ in $\left.\mathrm{H}_{2} \mathrm{O}\right)$ brass bellows gauge monitored positive pressures.

All heatings in an air environment were performed in basically the same furmace outlined for the helium and argon studies. However, a confining bell jar and gas train were not employed to control the environment. The system was left free to achieve the atmospheric conditions prevalent in the surroundings. To

${ }^{4}$ No attempt was made to remove nitrogen from either the helium or argon. The only impurities detected by mass spectrometric analysis were oxygen and nitrogen as air. The analyses were performed by the Analytical Chemistry Division, National Bureau of Standards. inhibit oxidation during the early stages of the heat treatment, facilities were available to engulf the susceptor in a stream of helium. The helium flowed through an orifice located in the crucible mount directly below the susceptor. A blower aided in removing vapors from the optical path of the pyrometer. The forced air was directed across the top of the induction coil but did not impringe on any part of the furnace. The stream of air caused no noticeable detrimental effect.

\section{c. Susceptor-Blackbody}

Figures 4 and 5 illustrate the significant elements of the susceptor-blackbody assembly which was used in conjunction with each of the described furnaces. Table 3 lists the nominal dimensions of each of crucibles. With the exception of the brass support mount, all parts were machined from solid rods of either pure iridium or tungsten. The all-tungsten assembly was employed for heatings in vacuum, argon, and helium. The iridium susceptor-blackbody was utilized for environments of vacuum, helium, and exclusively for air applications.

The outer crucible served as the susceptor and was heated inductively. The inner crucible in turn was

TABLE 3. Nominal dimensions of crucible assembly

\begin{tabular}{|c|c|c|}
\hline & $\begin{array}{l}\text { Outer crucible } \\
\text { "susceptor" }\end{array}$ & $\begin{array}{l}\text { Inner crucible } \\
\text { "blackbody" }\end{array}$ \\
\hline & & in \\
\hline Outer diameter & 0.75 & 0.50 \\
\hline Length & 1.25 & .75 \\
\hline Wall thickness & 0.06 & .06 \\
\hline Cover thickness & .06 & .06 \\
\hline Cover diameter & .75 & .50 \\
\hline Orifice diameter & .13 & .03 \\
\hline
\end{tabular}




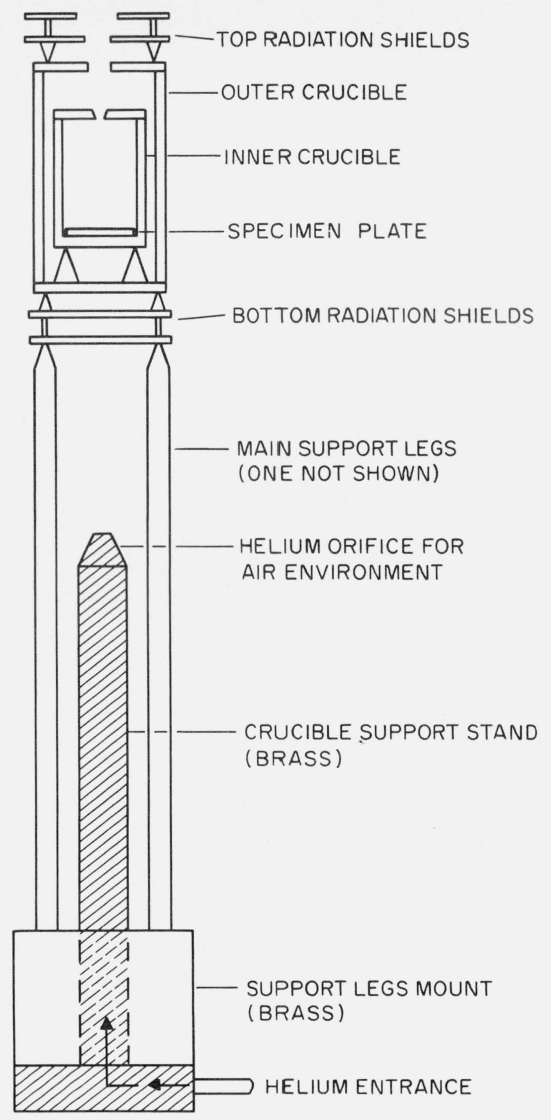

FIGURE 4. Schematic drawing of susceptor-blackbody and related parts.

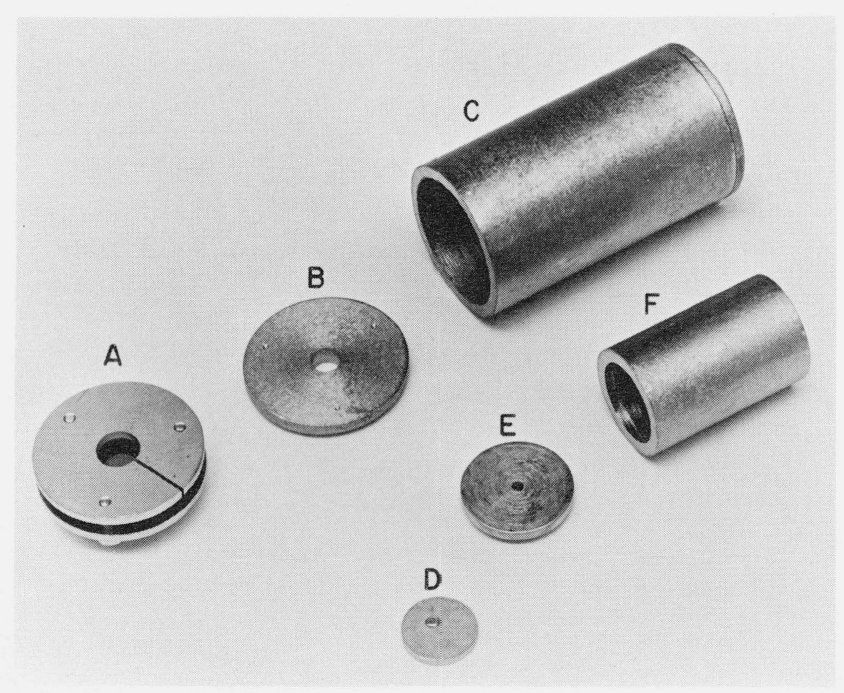

Figure 5. Photograph of susceptor-blackbody disassembled. $A=$ top radiation shields $\mathrm{B}=$ outer crucible cover

$\mathrm{C}=$ outer crucible and base

$\mathrm{D}=$ inner crucible

$\mathrm{D}=$ inner crucible
$\mathrm{E}=$ inner crucible cover

$\mathrm{F}=$ specimen plate containing melted $\mathrm{Al}_{2} \mathrm{O}_{3}$ sample

$\mathrm{G}=$ bottom radiation shields not shown. heated primarily by radiant energy emitted from the susceptor. In gaseous environments, energy transmitted by convection also influenced to a limited extent, the heating characteristics of the crucibles. The inner crucible performed a dual function, acting as both the specimen container and blackbody for temperature measurement. Each of the crucibles was supported on minimum contact pointed tungsten or iridium rods. This arrangement promoted temperature uniformity by minimizing heat flow to cooler areas. End losses were further reduced by radiation shields located at each end of the outer crucible. Each shield contained a 0.02 in wide slot to inhibit appreciable heating by induction. Successively larger holes in the outer crucible cover and top radiation shields permitted radiation emitted from the orifice in the inner crucible to pass through the glass window to the pyrometer. To insure diffuse reflections, all surfaces of the inner crucible and the internal surface of the outer crucible were grit blasted with $\mathrm{Al}_{2} \mathrm{O}_{3}$ powder. A removable specimen plate, 0.31 in diam, 0.04 in thick was located at the bottom of the inner crucible. A 0.03 in diam, 0.02 in deep depression in the plate, 0.05 in off center, provided a cavity for placement of the specimen.

\subsection{Temperature Measurement}

An automatic photoelectric pyrometer was used to monitor temperatures continuously during the course of each experiment. The photoelectric pyrometer is not a new innovation in temperature measurement, but only recently has it come of age as a precision piece of equipment. Since descriptions of this type of device are given elsewhere $[11,12]$, only pertinent details will be outlined here. Basically, the automatic pyrometer operates on the same general principle as the well-known visual optical pyrometer with a phototube performing the same function as the eye. The phototube detector, through a chopper arrangement, alternatively views images of the target and an internal calibrated standard lamp, each 90 times per second. A transitorized balancing mechanism automatically adjusts the emf to the lamp until the lamp brightness is equal to that of the target. The current drawn by the lamp can be then related directly to the brightness of the target. Once the current-temperature relationships of the internal lamp are established, the temperature of a blackbody target can be determined.

The photoelectric pyrometer, like the visual equipment, is a spectral instrument. A standard interference filter limits the band pass to a wavelength of 0.650 micrometers with a width at half height of about 0.020 micrometers. The pyrometer can respond in less than 1 sec to temperature changes of $0.2{ }^{\circ} \mathrm{C}$ at $1063{ }^{\circ} \mathrm{C}$ (gold point) and about $1{ }^{\circ} \mathrm{C}$ at $2000{ }^{\circ} \mathrm{C}$. Target sizes can be as small as 0.030 in diam requiring an entrance angle of 0.006 steradians. Internally mounted absorbing screens are used to reduce the amount of radiation reaching the photomultiplier tube and provide four separate ranges of operation: 800 to $1200{ }^{\circ} \mathrm{C}$ (low), 1050 to $1700{ }^{\circ} \mathrm{C}$ (medium), 1350 to $2800{ }^{\circ} \mathrm{C}$ (high), and 2000 to $6100{ }^{\circ} \mathrm{C}$ (extra high). 
The pyrometer was calibrated ${ }^{5}$ on two separate occasions, at the beginning of the experimentation and after $300 \mathrm{hr}$ of operation. Using a tungsten strip lamp as the temperature source and assuming a mean effective wavelength of 0.653 micrometers, the calibration related blackbody temperatures to corresponding currents of the internal pyrometer lamp. Table 4 gives selected low range values for each of the two calibrations. The data generally fit the equation:

$$
T=a+b I+c I^{2}+d I^{3}+e I^{4}
$$

where,

$$
\begin{aligned}
T & =\text { blackbody temperature, }{ }^{\circ} \mathrm{C} \text { IPTS } \\
I & =\text { pyrometer lamp current, milliamperes. }
\end{aligned}
$$

Overall there is a favorable comparison between the two sets of values, thus illustrating the stability of the pyrometer after extended use. Further tests indicated that moderate changes in ambient temperatures do not affect the calibrations.

Maximum uncertainties in the calibration are estimated to decrease from about $\pm 3{ }^{\circ} \mathrm{C}$ at $800{ }^{\circ} \mathrm{C}$ to $\pm 1.5{ }^{\circ} \mathrm{C}$ at $1063{ }^{\circ} \mathrm{C}$, and then increase to about $\pm 2{ }^{\circ} \mathrm{C}$ at $1225{ }^{\circ} \mathrm{C}$ for the low range. For the medium range, the uncertainties increase from $\pm 2{ }^{\circ} \mathrm{C}$ at $1100{ }^{\circ} \mathrm{C}$ to $\pm 3.5{ }^{\circ} \mathrm{C}$ at $1750{ }^{\circ} \mathrm{C}$, and for the high range, increase from $\pm 4{ }^{\circ} \mathrm{C}$ at $1500{ }^{\circ} \mathrm{C}$ to about $\pm 4.5{ }^{\circ} \mathrm{C}$ at $2000{ }^{\circ} \mathrm{C}$ and to about $\pm 6.5^{\circ} \mathrm{C}$ at $2800{ }^{\circ} \mathrm{C}$.

TABLE 4. Automatic pyrometer calibrations (low range)

\begin{tabular}{c|c|c}
\hline \hline & \multicolumn{2}{|c}{ Blackbody temperature } \\
$\begin{array}{c}\text { Pyrometer } \\
\text { lamp current }\end{array}$ & Original & After 300 hours \\
\cline { 2 - 3 } & & \\
\hline & & \\
Milliamperes & ${ }^{\circ}$ C, IPTS & ${ }^{\circ}$ C, IPTS \\
32.00 & 876 & 877 \\
35.00 & 930 & 931 \\
38.00 & 980 & 980 \\
41.00 & 1027 & 1027 \\
44.00 & 1072 & 1072 \\
47.00 & 1115 & 1115 \\
50.00 & 1156 & 1157 \\
53.00 & 1197 & 1198 \\
56.00 & 1237 & 1237 \\
& &
\end{tabular}

In the present work the pyrometer was mounted directly above the furnace, thereby eliminating the need for a prism and its additional source of error. The pyrometer was encased in an aluminum jacket which in turn was attached to a milling head-piston assembly. This arrangement allowed for vernier adjustment in the $x, y$, and $z$ directions as well as providing for rotational movement. In all cases the pyrometer was alined normal to the top surface of the inner crucible. The aluminum jacket served as an electrical shield against rf pickup and in addition, protected the pyrometer somewhat against changes in ambient temperature.

${ }^{5}$ The calibration was performed by the Radiation Thermometry Section, Heat Division, National Bureau of Standards.
Both the power input and emf output of the pyrometer were filtered and shielded against electrical interference. The lamp current was measured by a high speed precision milliampere recorder-indicator. Frequent calibrations proved the reliability of the recorder.

\subsection{Window Calibration}

The absorption characteristics of the fused silica viewing window were determined routinely throughout the course of the investigation. To accomplish this, the automatic pyrometer was rigidly fastened to one end of a lathe bed which served as an optical bench. A type $30 \mathrm{~A} / 6 \mathrm{~V}$ tungsten ribbon lamp, the temperature source, was mounted on the opposite end of the bench with a moveable window holder intermediate between the lamp and the pyrometer. The lamp carriage allowed for adjustments in the lamp position in the $x, y$, and $z$ directions as well as providing for angular and rotational movement. The tungsten ribbon and the window were aligned normal to the optic axis of the pyrometer.

Power for lamp operation was furnished by a regulated solid state d-c power supply having a capacity of 0 to $18 \mathrm{~V}$ and 0 to $50 \mathrm{~A}$. The power supply system was capable of maintaining a constant lamp current to within 0.02 percent, which is equivalent to less than $0.5{ }^{\circ} \mathrm{C}$ for a ribbon temperature of $2000{ }^{\circ} \mathrm{C}$. Currents drawn by the lamp were determined by measuring with a precision potentiometer, the potential drop across a $0.001 \Omega$ calibrated resistor in series with the lamp. Frequent spot checks on the accuracy and precision of the pyrometer were made possible through the use of a calibrated ribbon lamp. The lamp calibration ${ }^{5}$ related the current drawn by the lamp to its brightness temperature at a wavelength of 0.653 micrometer.

\section{Test Methods}

\subsection{Melting Point Determinations}

Although numerous methods have been devised for determining the melting point of a material, none appeared completely suitable for establishing the $\mathrm{Al}_{2} \mathrm{O}_{3}$ point. The traditional method, thermal analysis, depends upon energy changes which occur during heating or cooling and is reliable only for materials having a relatively high thermal conductivity. Other procedures require an accurate knowledge of difficult to obtain properties, such as emissivity, to establish the melting temperatures.

Perhaps the greatest difficulty inherent with any method is the measurement of temperature. The method finally adopted in the present investigation concentrated on this facet of the problem, the attainment of accurate temperatures. To accomplish this a blackbody enclosure was built as an integral part of the system. Secondly, a specimen of sufficiently small 
volume was utilized so as not to introduce unwanted thermal gradients and negate the attainment of blackbody conditions. In essence, the method simply consisted of the heating and cooling of a blackbody enclosure containing a specimen small enough not to disturb the blackness of the cavity. At all times during the heating or cooling cycle the specimen was invisible to the eye. A visible specimen would require a departure from blackbody conditions and thus defeat the purpose of enclosure. After each heating, it was necessary to classify the cooled specimen as either melted or not melted according to specified criteria. After a series of heatings the melting point could be established as that temperature midway between the maximum temperature at which no melting occurred and the minimum temperature where fusion was complete.

Quite obviously, the success of the method depends upon the ability to determine positively the degree of melting the specimen had undergone. Physical appearance of the specimen is a useful guide. A sample which had lost its original shape and flowed to surrounding regions can, of course, be considered completely melted. Unfortunately, the appearance can be deceptive at times due to plastic flow, creep and sintering which occur in the solid state. These difficulties were minimized to negligible problems by utilizing single crystals as test specimens. A single crystal will retain its identity, that is, remain single, unless melted. Upon melting, the liquid will solidify as a polycrystalline mass which is easily detected by microscopic techniques.

To insure the maximum degree of correlation between experiments performed in different environments, the same general procedure was followed for each individual test. A cylindrical-shaped single crystal (or polycrystalline specimen), about 0.03 in diam, 0.03 in long, was placed in the depression of the specimen plate located at the bottom of the inner crucible (blackbody). After assembly of the remainder of the susceptor-blackbody, the bell jar was positioned in place and the entire system evacuated by means of the mechanical pump. Using an auxiliary spotlight the pyrometer was alined and focused on the hole in the cover of the inner crucible.

Depending upon the required environment, either the system was evacuated further to about $2 \times 10^{-5}$ torr with the diffusion pump (fig. 1) or in cases of the atmosphere furnace (figs. 2 and 3), ourgassed by heating to $1000{ }^{\circ} \mathrm{C}$ at mechanical pump pressures. For argon or helium applications, after the preliminary heating in vacuum, the system was then filled with purified gas to a pressure of about 30 in $\mathrm{H}_{2} \mathrm{O}$ (gauge). The system was again evacuated and refilled with the entire flushing procedure being repeated a total of four times. After the final filling, the system was vented to the air through the bubbler. Gas flow was maintained at about $0.5 \mathrm{ml}$ per minute at a positive pressure of about 2 in $\mathrm{H}_{2} \mathrm{O}$. For heatings in air, the system was, of course, left open to the surrounding environment. To inhibit oxidation, a gentle flow of helium from the orifice below the susceptor did, however, engulf the crucible during the first $1200 \mathrm{deg}$. At this temperature the helium flow was terminated and the remainder of the heating cycle conducted in air. During the cooling cycle, the helium flow was reactivated.

The heating rates were the same regardless of the environment. After the preliminary processing was completed, the power to the generator was increased in a stepwise manner at about $10{ }^{\circ} \mathrm{C}$ per minute until the temperature was about 10 to $15 \mathrm{deg}$ below the desired temperature. The pyrometer was then realined by traversing across the sight area until the output of the pyrometer indicated a maximum. This position was found to coincide with the center of the hole in the inner crucible. The traversing procedure was necessary inasmuch as the inner hole was almost invisible to the eye due to the near blackbody conditions which prevailed in the area surrounding the smaller crucible. After realinement, the temperature was increased slowly at about $0.75{ }^{\circ} \mathrm{C}$ per minute until the desired temperature was attained. This temperature, $T_{m}$, was maintained about 30 to 60 secs before all power was shut off. Upon cooling, the entire assembly was dismantled and the specimen examined for evidence of melting. Routine examination included detailed analyses with both a binocular and polarizing microscope and, when applicable, x-ray diffraction.

In order to determine accurately the temperature attained in the vacuum, argon, or helium experiments, it was absolutely necessary to establish the absorption characteristics of the viewing window and deposited vapors. Window calibration was carried out by first positioning the window between the pyrometer and ribbon lamp in a manner as to similate test conditions in the induction furnace. The pyrometer was sighted through the window and focused on the midportion of the ribbon located adjacent to the filament notch. The lamp, representing the blackbody enclosure, was raised in temperature until the pyrometer indicated an output approximating the maximum obtained in the melting point test. After proper stabilization, adjustments were made until the brightness temperature of the lamp was within $2{ }^{\circ} \mathrm{C}$ of the experimental run. With the temperature of the lamp held constant the window was removed from the optical path causing an increase in the output of the pyrometer. The absorption of radiation due to the window and deposited vapors could be accounted for through the calculation of the " $A$-value" obtained from the equation:

$$
\frac{1}{T_{t}}-\frac{1}{T_{a}}=A
$$

where,

$T_{t}=$ temperature $\left({ }^{\circ} \mathrm{K}\right)$ observed without the window in the optical path

$T_{a}=$ temperature $\left({ }^{\circ} \mathrm{K}\right)$ observed through the window. 
Once $A$ was determined, it could be applied to the melting point test by substituting $T_{m}$ for $T_{a}$ in the above equation. Solving for $T_{t}$ a temperature is obtained which should be equivalent to the maximum temperature actually attained by the blackbody and specimen. This assumes, of course, that blackbody conditions prevailed during experimentation. It further assumes that no significant amount of vapors were deposited on the window during cooling and that no appreciable quantity of radiation was absorbed by vapors in the optical path of the pyrometer.

\subsection{Arc-Image and Phase Equilibria Experiments}

In order to determine what effect various environments have upon $\mathrm{Al}_{2} \mathrm{O}_{3}$, a number of experiments were performed using arc imaging techniques. The arc-image furnace has been described elsewhere [13] and therefore will not be outlined here. The procedure followed essentially consisted of purifying a polycrystalline rod of $\mathrm{Al}_{2} \mathrm{O}_{3}$ by melting for $\mathrm{l} \mathrm{hr}$ in a vacuum of $5 \times 10^{-6}$ torr. The temperature of the molten $\mathrm{Al}_{2} \mathrm{O}_{3}$ was estimated to be about $2150{ }^{\circ} \mathrm{C}$. After the initial treatment, the specimen was remelted for $10 \mathrm{~min}$ at the same temperature in about 1 atm $(770$ to $780 \mathrm{~mm} \mathrm{Hg})$ of the desired gas. Environmental gas included: air, air plus water vapor, helium, helium plus water vapor, hydrogen, nitrogen, and oxygen. All specimens were then examined with the polarizing microscope using the immersior method (1.760 index liquid and 500X magnification).

In addition to the arc-image experiments, a limited study was conducted on the phase equilibrium relationships in the $\mathrm{Al}_{2} \mathrm{O}_{3}$-W and in the $\mathrm{Al}_{2} \mathrm{O}_{3}$ - Ir systems in vacuum, helium, and where appropriate, air. The same equipment and general procedure previously described for the melting point determinations were employed in this auxiliary investigation. Heating schedules were modified slightly to allow for longer holding periods at the desired temperature. Evidence for melting was based solely upon the physical appearance of the cooled specimen. All specimens were examined by $x$-ray diffraction at room temperature using a high-angle recording Geiger-counter diffractometer and $\mathrm{Ni}$-filtered $\mathrm{Cu}$ radiation.

\section{Materials and Specimen Preparation}

Four single crystals and one powdered sample of $\mathrm{Al}_{2} \mathrm{O}_{3}$ were used for all melting point determinations. Table 5 gives the general qualitative spectrochemical anslysis ${ }^{6}$ of each material.

The single crystals, 0.03 in diam, 6 in long, were purchased from the same supplier in two different lots of 8 to 10 crystals each. The four single crystal samples were selected at random, three from one lot and one from the other. Specimens were prepared from individual rods by cutting them with a diamond saw into 0.03 in lengths. The cut specimens were washed in alcohol, boiled in $\mathrm{HCl}$, washed in distilled water, and finally dried at $140{ }^{\circ} \mathrm{C}$.

The powdered sample, as received, was in the form of a fine, apparently amorphous material. Upon heating, the amorphous powder readily converted to polycrystalline $\alpha-\mathrm{Al}_{2} \mathrm{O}_{3}$. Specimens were prepared from the as received powder by pressing into 0.03 in diam, 0.03 in long, cylinders using a small pellet press. Distilled water was added to the $\mathrm{Al}_{2} \mathrm{O}_{3}$ to aid in the fabrication. Other than air-drying, the specimens received no additional treatment.

All specimens for the phase equilibria study were fabricated from 99.9 percent pure $W$ or Ir powder and the same $\mathrm{Al}_{2} \mathrm{O}_{3}$ powder as used for the melting point tests. Compositions prepared for study were limited to: $90 \mathrm{Al}_{2} \mathrm{O}_{3}: 10$ metal, $66.7 \quad \mathrm{Al}_{2} \mathrm{O}_{3}: 33.3$ metal and $50 \mathrm{Al}_{2} \mathrm{O}_{3}: 50$ metal (mole percent). Appropriate amounts of $\mathrm{Al}_{2} \mathrm{O}_{3}$ and either $\mathrm{W}$ or $\mathrm{Ir}$ were first mechanically mixed, then pressed into 0.03 or 0.06 in diam pellets and finally air dried.

${ }^{6}$ Analyses were performed by the Analytical Chemistry Division, National Bureau of Standards.

TABIE 5 . General qualitative spectrochemical analyses of various $\mathrm{Al}_{2} \mathrm{O}_{3}$ samples ${ }^{\text {a }}$

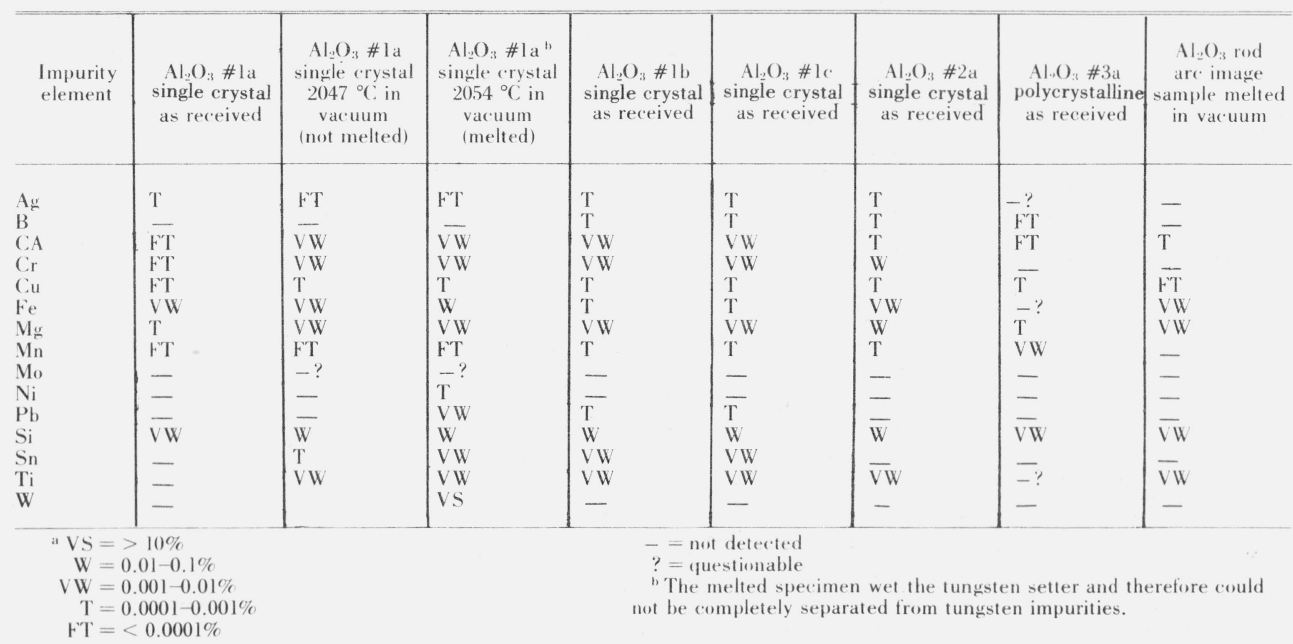


Specimens for the arc-image experiments were purchased in the form of sintered polycrystalline rods, about 0.25 in in diam. The rods were purified by vacuum melting as previously described. They received no other treatment prior to the actual test. Table 5 lists the spectrochemical analyses of a rod after purification.

\section{Results and Discussion}

\subsection{Temperature Measurement}

In spectral radiation pyrometry, as employed in this investigation, the measuring instrument determines a brightness temperature, not the true temperature of an incandescent body. Using Wien's law, ${ }^{7}$ the relationship between these two temperatures is given by the equation:

$$
\frac{1}{T}-\frac{1}{T_{B}}=\frac{\lambda_{e}}{C_{2}} \ln E_{\lambda}
$$

where,

$$
\begin{aligned}
T & =\text { true temperature }\left({ }^{\circ} \mathrm{K}\right) \\
T_{B} & =\text { brightness temperature }\left({ }^{\circ} \mathrm{K}\right) \\
\lambda_{e} & =\text { effective wavelength } \\
E_{\lambda} & =\text { spectral emissivity } \\
C_{2} & =\text { second radiation constant. }
\end{aligned}
$$

Quite obviously, for a given effective wavelength the difference between $T$ and $T_{B}$ may be rather large, depending upon the magnitude of the spectral emissivity. Unfortunately, emissivity is a very difficult property to determine experimentally and consequently is known for but a few materials. The practical approach to the problem is to incorporate a a blackbody in the measuring system. Since a blackbody, by definition, has an emissivity of unity, the observed and true temperatures necessarily would be equal.

Fundamental to the present investigation is the assumption that near blackbody conditions were attained by the inner crucible enclosure during experimentation. A perfect blackbody would represent an ideal situation, but this unfortunately cannot be achieved experimentally. Estimates must be made of the extent of the deviation from perfection. The quality of the blackbody can be determined from a knowledge of the geometrical design, and the reflectivity and natural emissivity of the materials of construction [14, 15]. Using the equations of Gouffé [14], the effective emittances of the blackbody containers were calculated from the dimensions listed in table 3 and from published emissivity values of iridium and tungsten $[5 ; 16,17,18,19]$. For the tungsten blackbody, the effective emittances were 0.999 at room temperature and 0.998 at $2700{ }^{\circ} \mathrm{C}$. The deviations in emittance from unity will cause an error of

${ }^{7}$ Ideally, the Planck equation should be utilized since Wien's radiation formula is not strictly valid at extremely high temperatures. However, if $\lambda(t+273)$ is less than $0.3 \mathrm{~cm} \mathrm{deg}$ the resulting error is less than $1{ }^{\circ} \mathrm{C}$. less than $1{ }^{\circ} \mathrm{C}$ at $2700{ }^{\circ} \mathrm{C}$. At room temperature the effective emittance of the iridium blackbody was calculated as 0.998 . Values at other temperatures could not be estimated because of the lack of reliable high temperature emissivity data for iridium.

The calculations are estimates and only valid if (1) the blackbody enclosure is uniformly heated, and if (2) the internal reflections are completely diffuse rather than specular. Any deviation from these two requirements would lower the effective emittance and cause significant errors in the temperature measurements. An attempt was made to insure diffuse reflections by grit blasting the surfaces of the crucibles prior to each test. The effectiveness of this procedure is unknown. However, the tungsten surfaces always remained roughed and dull after each heating. The iridium surfaces on the other hand, always, upon heating in vacuum or inert atmospheres changed from the dull appearance caused by the grit blasting to a bright shiny surface. These observations suggest that the effective emittance calculations might be more appropriate for the tungsten blackbody than for the iridium.

Temperature uniformity is perhaps even more difficult to verify. The radiation shielding obviously helped to promote uniform temperatures not only by limiting the escape of emitted radiation, but also by acting as susceptors of the induction field and thus producing independent sources of heat. Care was taken during the initial positioning of the crucibles in the induction coils to see that at least the outer crucible surfaces were uniformly heated. Using a manual pyrometer to measure the brightness temperature of the vertical outer surfaces, the position of the crucible was adjusted until no gradients were indicated. The relatively high thermal conductivity of tungsten and iridium were perhaps the greatest aid in assuring temperature uniformity. Even gross misalinement of the crucibles in the induction field did not produce significant gradients. Further tests for temperature uniformity were conducted by heating simultaneously a number of $\mathrm{Al}_{2} \mathrm{O}_{3}$ single crystal specimens located on various parts of the specimen plate. In every test, all specimens behaved in a similar manner, that is, the same degree of melting was indicated for each.

A definite indication of the relative quality of the blackbody and associated temperature uniformity was obtained in a manner pointed out by Kostkowski and Lee [20]. With reference to figure 4 it is evident that the upper portion of the outer crucible (susceptor) represents another blackbody having an effective emittance for tungsten calculated to be 0.960 at room temperature and 0.958 at $2700{ }^{\circ} \mathrm{C}$. If both the upper blackbody and the inner enclosure are at the same temperature, the brightness temperature of each would be different by an amount related to their respective emittances with the inner blackbody always appearing the brighter. Calculated differences between corresponding brightness temperatures varied between $3{ }^{\circ} \mathrm{C}$ at $1000^{\circ} \mathrm{C}$ and $10.5^{\circ} \mathrm{C}$ at $2100{ }^{\circ} \mathrm{C}$. 
These apparent differences in brightness were measured at various temperatures by alternately sighting the pyrometer first on the hole in the inner crucible and then on its top surface. Data were obtained for three sets of conditions: (1) Tungsten crucibles in vacuum, (2) tungsten crucibles in helium, and (3) iridium crucibles in / helium. The results of these experiments are given in figure 6 . The solid line represents the differences calculated from the effective emittances for the tungsten blackbodies. The circles and triangles indicate measured differences. The correlation was excellent considering that it was assumed that the two blackbodies were always at the same temperature. Maximum deviation from the calculated differences for tungsten was $2{ }^{\circ} \mathrm{C}$ both in vacuum and helium environments. The data for the iridium blackbodies were included strictly for comparative purposes since calculated differences (solid line) apply only to the tungsten enclosures.

Although these tests yielded generally favorable results, it was thought advisable to obtain more direct verification of the quality of the blackbodies and the temperature measuring system. The melting points of $\mathrm{Au}\left(1063^{\circ} \mathrm{C}\right), \mathrm{Pt}\left(1769^{\circ} \mathrm{C}\right)$, and $\mathrm{Rh}\left(1960^{\circ} \mathrm{C}\right)$ were determined selectively in a manner similar to that previously described for the $\mathrm{Al}_{2} \mathrm{O}_{3}$ determinations. At least one, generally two, metal melting points were investigated for all possible combinations of environments and container materials. To prevent direct reaction with the tungsten or iridium containers, the test specimen was placed in a shallow cavity in a 0.125 in diam, 0.125 in long $\mathrm{Al}_{2} \mathrm{O}_{3}$ single crystal which in turn rested on the specimen plate. The specimen consisted of a small metal fragment cut from 99.9 percent pure metal ribbon. Complete fusion was indicated by the formation of a spherical-shaped ball from the original platelike specimen.

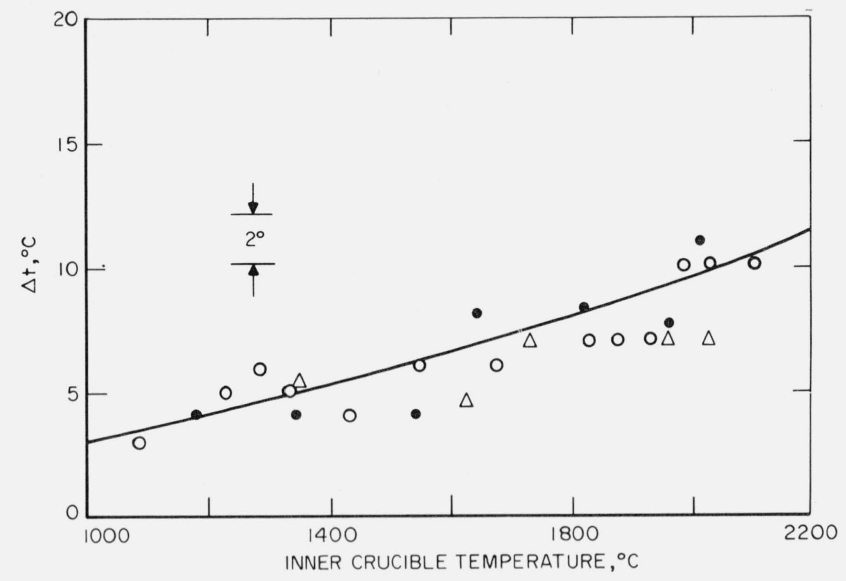

FIGURE 6. Brightness Temperature Differences

Solid line $=$ calculated differences in brightness temperatures for two tungsten black bodies.

$\Delta T=$ temperature of inner erucible minus temperature of outer enclosure.

$0=$ measured differences for tungsten blackbodies in vacuum

- = measured differences for tungsten blackbodies in helium.

$\Delta=$ measured differences for iridium blackbodies in helium.
Overall the standard metal study was of limited use in establishing the quality of the blackbodies. For the most part the results generally indicated the melting points of the metals as experimentally determined in this study agreed with the reported values to within the precision of the method, $\pm 0.5^{\circ} \mathrm{C}, \pm 1{ }^{\circ} \mathrm{C}$, and $\pm 1.5{ }^{\circ} \mathrm{C}$ for the $\mathrm{Au}, \mathrm{Pt}$, and $\mathrm{Rh}$ points, respectively.

The gold point tests proved to be the most reliable guide, checking out in every instance. At higher temperatures, depending upon the environment and container, the $\mathrm{Pt}$ and $\mathrm{Rh}$ determinations were not always conclusive. Notable discrepancies between reported and observed values occurred which in all probability can be attributed to causes other than the blackbody or temperature measuring system. Platinum for instance was found to melt in an inconsistent manner when heated in the tungsten crucible in vacuum. Platinum which had been previously melted invariably fused at temperatures lower than $\mathrm{Pt}$ receiving no prior treatment, perhaps indicating a possible reaction between the $\mathrm{Al}_{2} \mathrm{O}_{3}$ single crystal and the test specimen.

All attempts to determine the melting points of $\mathrm{Pt}$ and $\mathrm{Rh}$ utilizing the iridium crucible in air proved fruitless. In every test, both metals melted at temperatures considerably higher than expected. These metals were found to react with the Ir and/or Ir oxide vapor prevalent in the immediate surroundings to form Ir-Rh (or Ir-Pt) solid solutions which would have melting points higher than the $\mathrm{Rh}$ (or $\mathrm{Pt}$ ). X-ray diffraction patterns of $\mathrm{Pt}$ or $\mathrm{Rh}$ strips heated for short times showed reflections identifiable with almost pure Ir. When the surfaces of strips were ground, the resulting $x$-ray pattern was indicative of a single solid solution phase having a composition containing considerable Ir.

Additional problems were encountered in checking the $\mathrm{Rh}$ point in argon or helium environments. The melting point of $\mathrm{Rh}$ as observed was approximately $5{ }^{\circ} \mathrm{C}$ lower than the reported value. The explanation for this phenomenon apparently is not as straightforward as a simple chemical reaction. $\mathrm{X}$-ray patterns of $\mathrm{Rh}$ strips heated to just below melting showed no reflections whatsoever. Internal surfaces produced only broad ill-defined x-ray peaks of Rh. Upon heating, the crystalline starting material apparently became amorphous (to $\mathrm{x}$-rays) as the result of helium or argon environments. An amorphous material, of course, can be expected to melt at a temperature lower than a crystalline material of the same composition. Similar experiments conducted on $\mathrm{Pt}$ indicated opposite results. The $\mathrm{Pt}$ remained crystalline throughout the heat treatment and was found to have a melting point in agreement with the accepted value.

Additional experiments are needed to elucidate more fully the basic principles behind each of the various discrepancies outlined. All would be complete investigations in their own right and therefore will not be pursued further at this time. 


\subsection{Phase Equilibria}

Congruent melting indicates an equilibrium situation between a solid and liquid of the same chemical composition. Implicit is the requirement that both the solid and liquid represent the equilibrium phases defined only by the pressure-temperature relationships. Once the confining pressure is specified, the melting temperature is fixed and cannot change unless the equilibrium conditions are disrupted. Nevertheless, variations in the melting point are often observed experimentally. Pressure effects are normally small and generally can be disregarded for limited changes in pressure. The formation of metastable phases prior to melting may be a causative factor. The melting point of a nonequilibrium phase could not be expected to be equivalent to that of the stable modification. Major changes in the melting point of an oxide usually are associated with changes in composition induced through dissociation (or oxidation), or reaction with the container and environment.

Knowledge of the phase equilibrium relations of appropriate systems can give some insight as to the type of reaction or behavior which could be expected under specific conditions. In the present work a multicomponent system would be required for study if all the impurity elements in the $\mathrm{Al}_{2} \mathrm{O}_{3}$ specimens are considered. The impurities would cause a change in the melting point calculated to be less than a $1{ }^{\circ} \mathrm{C}$ depression for 0.2 mole percent contaminant. Neglecting these, however, the Al-W-O and Al-Ir-O ternary systems under appropriate environmental conditions would completely describe possible reactions. A complete study of each of these two systems would be difficult to accomplish experimentally; consequently, an investigation into only certain aspects must suffice.

Consider first the effect of dissociation of $\mathrm{Al}_{2} \mathrm{O}_{3}$ upon the melting point. In this situation the Al-O system becomes pertinent. Various compilations $[21,22]$ give only limited data on this system. Motzfeldt and Gitlesen [23] report preliminary data on the $\mathrm{Al}-\mathrm{Al}_{2} \mathrm{O}_{3}$ system and indicate no reaction occurs between end members in the solid state. Hoch and Johnston [24] claim the existence of solid $\mathrm{Al}_{2} \mathrm{O}$ and $\mathrm{AlO}$, but their work cannot be verified. According to Motzfeldt and Gitlesen [23] the addition of $\mathrm{Al}$ to $\mathrm{Al}_{2} \mathrm{O}_{3}$ lowers the $\mathrm{Al}_{2} \mathrm{O}_{3}$ point a measurable amount. An eutectic was placed at about 7 mole percent Al. Figure $8 \mathrm{a}$ indicates the general configuration of the $\mathrm{Al}-\mathrm{Al}_{2} \mathrm{O}_{3}$ system postulated from available information. In the figure $\mathrm{A}$ represents $\mathrm{Al}$; and $\mathrm{B}, \mathrm{Al}_{2} \mathrm{O}_{3}$. It is readily apparent from the diagram that gross dissociation of $\mathrm{Al}_{2} \mathrm{O}_{3}$ below melting would result in a two-phase assemblage, each probably detectable experimentally. Regardless of the total composition of the resultant mixture, melting occurs over a range of temperatures different from that of either end member. Although not indicated by the figure, oxygen deficient $\mathrm{Al}_{2} \mathrm{O}_{3}\left(\mathrm{Al}_{2} \mathrm{O}_{3}\right.$ solid solution) conceivably could exist. Here too, melting would occur over a range.

The arc-image experiments were conducted specifically to obtain information on the dissociation characteristics of $\mathrm{Al}_{2} \mathrm{O}_{3}$ under various environmental conditions. Microscopic examination of the various samples indicated quite definitely that some reduction of $\mathrm{Al}_{2} \mathrm{O}_{3}$ takes place upon heating in all the environments investigated. All samples contained vacuoles and occlusions of low indices $(<1.760)$. The vacuoles exhibited the shape of flowing droplets suggesting that they were originally composed of a second liquid phase consistent with the postulated $\mathrm{Al}-\mathrm{Al}_{2} \mathrm{O}_{3}$ system. This liquid could have been formed by the melting of impurities but most probably was the result of dissociation. Quantitative estimates of extent of dissociation were difficult to obtain. It appears that melting in vacuum had the least deleterious effect. Environmental gases, however, affected the $\mathrm{Al}_{2} \mathrm{O}_{3}$ to a greater degree and as measured by the amount of occlusions, the extent of dissociation for a particular environment increased in the following order: (1) vacuum, (2) $\mathrm{Ar}$, (3) $\mathrm{N}_{2}$, (4) $\mathrm{O}_{2}$, (5) $\mathrm{He}$, (6) air, (7) He + water vapor, (8) air + water vapor, and (9) $\mathrm{H}_{2}$. Surprisingly the presence of water vapor enhanced the detrimental effect. Normally water vapor would not be sonsidered as a reducing agent. However, the effect could be accounted for if the water itself dissociated to hydrogen and oxygen with the hydrogen preferentially attacking the $\mathrm{Al}_{2} \mathrm{O}_{3}$. An alternative explanation would be a reaction between $\mathrm{Al}_{2} \mathrm{O}_{3}$ and $\mathrm{H}_{2} \mathrm{O}$ in which $\mathrm{AlOH}$ gas is one of the prominent products.

Single crystal specimens heated in the iridium or tungsten crucibles during the melting point tests were also examined microscopically. Results comparable to the arc image tests were indicated with the vacuum treatments having the least effect and the air the greatest. No differences were detected between specimens heated in the same environment but using different container materials (W or Ir).

Originally it was believed that $\mathrm{x}$-ray examination might have detected $\mathrm{Al}_{2} \mathrm{O}_{3}$ solid solution or perhaps the presence of the predicted second solid phase, Al. However, x-ray patterns of the specimens optically examined showed only reflections representing $\alpha$ $\mathrm{Al}_{2} \mathrm{O}_{3}$. The unit cell dimensions, determined from back reflection measurements, were the same as those of the unheated starting materials. Apparently the dissociation process follows the equation generally postulated in vapor pressure studies [25]:

$$
\mathrm{Al}_{2} \mathrm{O}_{3(s, l)} \rightarrow 2 \mathrm{Al}_{(g)}+30_{(g)} 8
$$

Optical evidence supports this conclusion in that the vacuoles indicated vaporized regions. Even though dissociation is prevalent, the only condensed phase present during melting is stoichiometric $\mathrm{Al}_{2} \mathrm{O}_{3}$, solid or liquid. Consequently, the total composition probably would remain relatively constant and an experimentally determined melting point should be indicative of that of pure $\mathrm{Al}_{2} \mathrm{O}_{3}$ providing extraneous factors do not alter the equilibrium conditions.

\footnotetext{
${ }^{8}$ Other vapor species have been identified and include: $\mathrm{AlO}, \mathrm{Al}_{2} \mathrm{O}, \mathrm{Al}_{2} \mathrm{O}_{2}$. The concentration of these are minor in comparison with the major phases.
} 
Consideration should also be given to the effect of container materials upon the melting point of $\mathrm{Al}_{2} \mathrm{O}_{3}$. Any combination of materials, when in equilibrium, must undergo some type of reaction upon melting. The reaction will result in a change in the liquidus curve regardless of the extent of combination in the solid state. For dissimilar materials such as $\mathrm{Al}_{2} \mathrm{O}_{3}$ and $\mathrm{W}$, and $\mathrm{Al}_{2} \mathrm{O}_{3}$ and $\mathrm{Ir}$, one can expect large regions of liquid immiscibility and no compound formation. The phase equilibrium relations of the $\mathrm{Al}_{2} \mathrm{O}_{3}-\mathrm{W}$ and the $\mathrm{Al}_{2} \mathrm{O}_{3}$-Ir condensed systems probably can be represented by figure $7 \mathrm{a}$ with $\mathrm{A}$ indicating $\mathrm{Al}_{2} \mathrm{O}_{3}$ and $\mathrm{B}$, the metallic constituent, W or Ir.

The validity of these predicted diagrams was tested by limited experimental studies of the $\mathrm{Al}_{2} \mathrm{O}_{3}$ - W and $\mathrm{Al}_{2} \mathrm{O}_{3}$-Ir systems utilizing both helium and vacuum environments. In essence, the data indicated that as expected, solid state reaction between $\mathrm{Al}_{2} \mathrm{O}_{3}$ and the metals did not occur to any measurable degree. X-ray patterns of intimate mixtures heated to within $15^{\circ} \mathrm{C}$ of melting showed the presence of only $\alpha-\mathrm{Al}_{2} \mathrm{O}_{3}$ and $\mathrm{W}$ or Ir. The formation of intermediate compounds or solid solutions were not evident. Melting point experiments conducted on the mixtures indicated that the solidus temperatures were not significantly different from that of 100 percent $\mathrm{Al}_{2} \mathrm{O}_{3}$. Within the precision of the

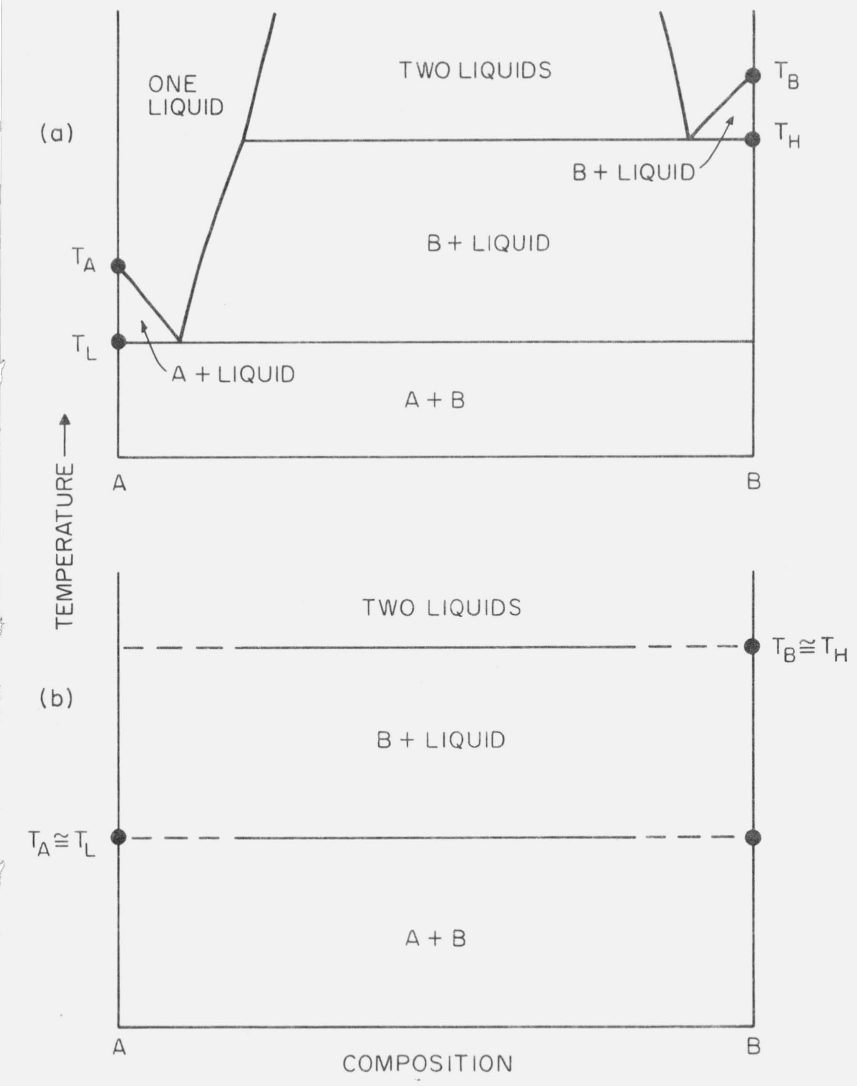

FigURE 7. Hypothetical phase diagrams for two dissimilar materials.

$A$ and $B=$ condensed phases having different chemical compositions

$T_{A}=$ melting point of phase $\mathrm{A}$

$T_{B}=$ melting point of phase $\mathrm{B}$

$T_{L}$ and $T_{\|}=$solidus temperatures. method the necessary change in liquidus temperatures could not be detected. Evidently the melting point of $\mathrm{Al}_{2} \mathrm{O}_{3}\left(T_{A}\right)$ and the solidus temperature $\left(T_{L}\right)$ are approximately equal and the phase diagram illustrated by figure $7 \mathrm{~b}$ is more indicative of actual relationships found in the $\mathrm{Al}_{2} \mathrm{O}_{3}-\mathrm{W}$ and $\mathrm{Al}_{2} \mathrm{O}_{3}$ - $\mathrm{Ir}$ systems.

The melting point data for the $\mathrm{Al}_{2} \mathrm{O}_{3}-\mathrm{W}$ system presented here and in the preliminary report [8] are in apparent contradiction with the work of Grossman [26] who states that the solidus temperature $\left(T_{L}\right)$ is $1997 \pm 20^{\circ} \mathrm{C}$. Grossman based his conclusions on cooling curve data of $\mathrm{Al}_{2} \mathrm{O}_{3}$ sealed in a tungsten container. Metallographic examination of the thermal analysis capsules indicated primary tungsten $(<1 \%)$ in the $\mathrm{Al}_{2} \mathrm{O}_{3}$ near the bottom of the containers. Although Grossman attributes the disagreement in results to the kinetics of the reaction, that is, nonequilibrium in the present work, it is postulated that his data pertains to systems other than the $\mathrm{Al}_{2} \mathrm{O}_{3}-\mathrm{W}$ binary, perhaps the Al-W system. From the previous discussion it is evident that $\mathrm{Al}_{2} \mathrm{O}_{3}$ itself dissociates to $\mathrm{Al}$ and oxygen. The vapor in a sealed system could then unite with the $W$ to form one or more of a number of phases having a lower melting point. Further evidence for vapor-solid reactions is presented by Grossman who points out that the greatest dissolution of $\mathbb{W}$ occurs near the top of the capsule. In an open system as utilized in this investigation, a dynamic situation occurs in which any $\mathrm{Al}$ vapor is carried away. More data is needed before this question can be fully resolved. X-ray data on the included tungsten would be extremely useful.

The phase relationships would, of course, represent the extreme situation where chemical equilibrium has been attained between the container materials and $\mathrm{Al}_{2} \mathrm{O}_{3}$. This was not necessarily the case in the melting point experiments. Minimum contact between the $\mathrm{Al}_{2} \mathrm{O}_{3}$ specimen and the $\mathrm{W}$ or $\mathrm{Ir}$ setter plate considerably reduced the possibility of significant reaction. Spectrochemical analyses of $\mathrm{Al}_{2} \mathrm{O}_{3}$ specimens heated in vacuum, helium, or argon to temperatures just below the melting point supported the no reaction hypothesis. The analysis for $\mathrm{Al}_{2} \mathrm{O}_{3}$ heated in tungsten in vacuum, table 5 , shows no assimilation of the metal by the oxide whatsoever, as would be required for reaction. Although not given in the table, similar analyses were obtained for samples heated in helium and argon utilizing both the tungsten and iridium crucibles. Analyses of specimens heated in air in iridium were not performed due to heavy deposits of $\mathrm{IrO}_{2}$ which always coated the sample during cooling. Any analysis would always indicate the presence of Ir irregardless of the degree of interaction.

Thus far the discussion has been limited to the influence of chemical factors, dissociation and reaction, have upon the melting point of $\mathrm{Al}_{2} \mathrm{O}_{3}$. In recent years the phenomena commonly termed "premelting" has been related to observed variation in the melting temperature. Ubbelohde in his book "Melting and Crystal Structure" [27] gives an excellent description of "premelting." In essence, premelting refers, 
not to the melting of impurity components, but to an anomaly occurring in the solid which causes lower melting temperatures. The extent of the anomaly determines the melting temperature with gross effects graphically illustrated by enhanced curvature in thermal curves near the melting arrest. These anomalies normally are associated with vibrational disorders or with defects of various types and result in the formation of lower melting quasi-crystalline materials distinctly different from their more crystalline counterparts. In addition to premelting, other properties including thermal expansion and heat capacity should show abnormal behavior indicative of a defect nature.

The rhodium melting point studies conducted in this investigation perhaps provide an excellent example of the premelting phenomenon. Here the Rh surface reverted to a noncrystalline state and in effect produced a lower melting material. The exact causes for the amorphous nature of the Rh are difficult to determine; however, they are apparently related to the high temperature gaseous environments of helium or argon. The mechanism whereby the gas destroys the crystallinity of the Rh is unknown. It may be that the bombardment of the metal by high velocity gas atoms or ions produced the quasi-crystalline material needed for premelting. Darken and Gurry [28], however, point out that the polarization power of gaseous environments, including the inert gases, may have a profound affect upon certain thermodynamic properties. In this context helium would be expected to have greater effect than argon. Vacuum treatment, of course, would be ineffectual.

Evidence for premelting of $\mathrm{Al}_{2} \mathrm{O}_{3}$ has been given by Gitlesen and Motzfeldt [29] who noted irregularities in heating curves 20 to $30^{\circ} \mathrm{C}$ below the observed melting point. Kozlovskii and Shlyakova [30] suggest a partial destruction of the structure at high temperatures. Supporting heat capacity data is offered by Kantor et al., [31]. Barber and Tighe [32] showed that $\mathrm{Al}_{2} \mathrm{O}_{3}$ (sapphire) heated at $1900{ }^{\circ} \mathrm{C}$ in a mixture of argon and nitrogen produces surface effects different from that obtained by vacuum treatment. The gas treated surfaces were coated with porous material concluded to be $\mathrm{Al}_{2} \mathrm{O}_{3}$ but not necessarily the $\alpha$ form.

Under normal circumstances premelting originates at the surface and for large volumes, the bulk of the material remains predominantly unaffected. Depending upon the permeability of the solid $\mathrm{Al}_{2} \mathrm{O}_{3}$ the environmental gas could be expected to penetrate to certain depths and as the outer layer is premelted, permeate even further until eventually the entire sample is molten. It is apparent that the extent of premelting is governed by, among other factors, the surface area to bulk volume of the sample. Gitlesen and Motzfeldt [29] utilized a relatively large mass of $\mathrm{Al}_{2} \mathrm{O}_{3}$ in their experiments and had only minor indications of premelting. If the mass of the sample is considerably reduced as in the present work the premelting phenomenon is accentuated to such a degree that it is the predominate effect. Consequently, differences in the melting point should be observed for different environments, as is the case.

\subsection{Melting Point of $\mathrm{Al}_{2} \mathrm{O}_{3}$}

Table 6 gives the experimental results obtained in the determination of the melting points of five samples of $\mathrm{Al}_{2} \mathrm{O}_{3}$. Each entry represents a single experiment conducted on a different test specimen. The listed temperatures have been adjusted to account for the necessary window corrections. The observed melting point for each sample is given below the separate listings. Table 7 summarizes the data tabulated in table 6 and indicates the melting point of $\mathrm{Al}_{2} \mathrm{O}_{3}$ appropriate to the container and environment specified.

TABLE 6. Experimental data on the melting point of various $\mathrm{Al}_{2} \mathrm{O}_{3}$ samples

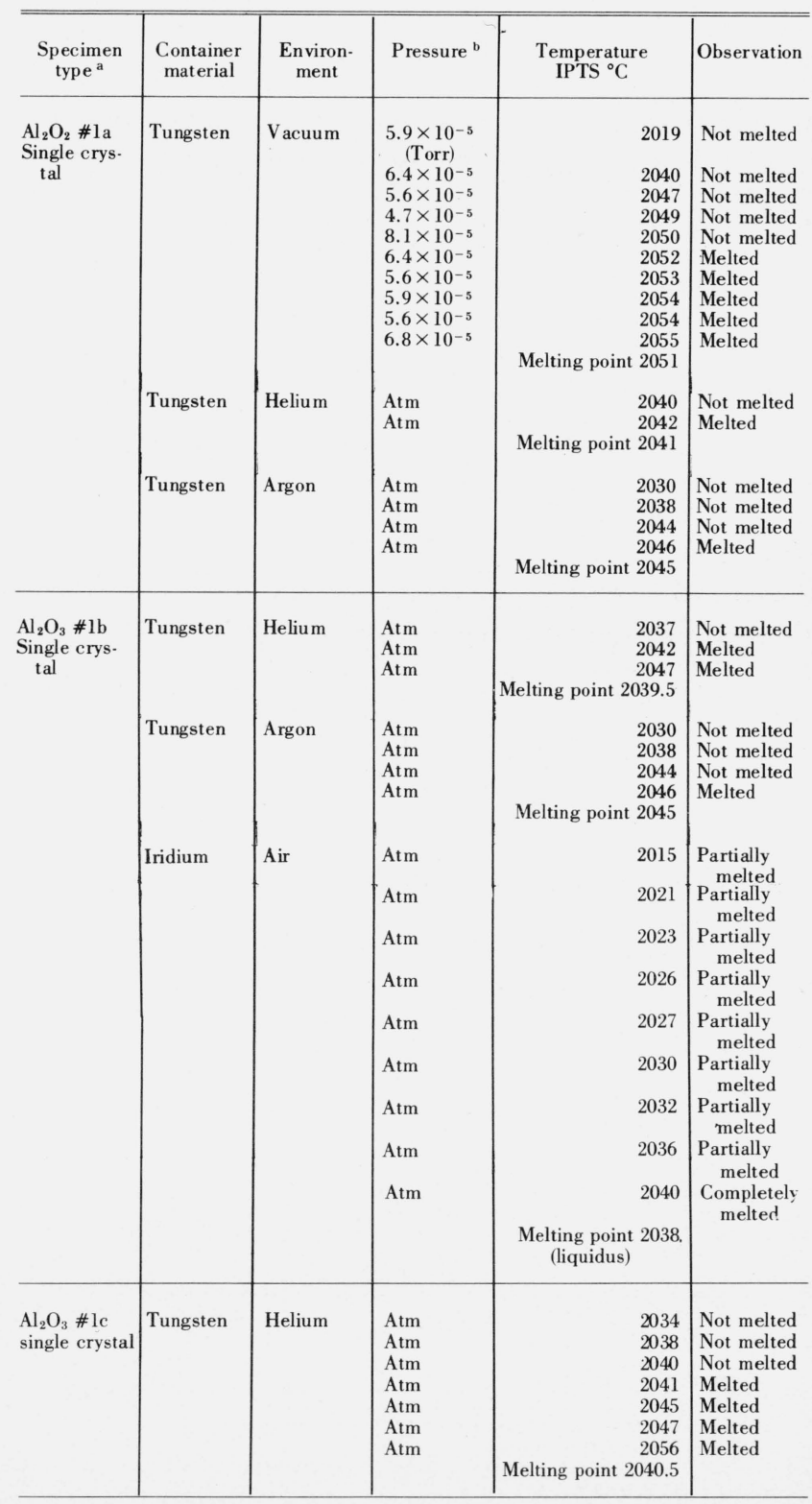


TABLE 6. Experimental data on the melting point of various $\mathrm{Al}_{2} \mathrm{O}_{3}$ samples - Continued

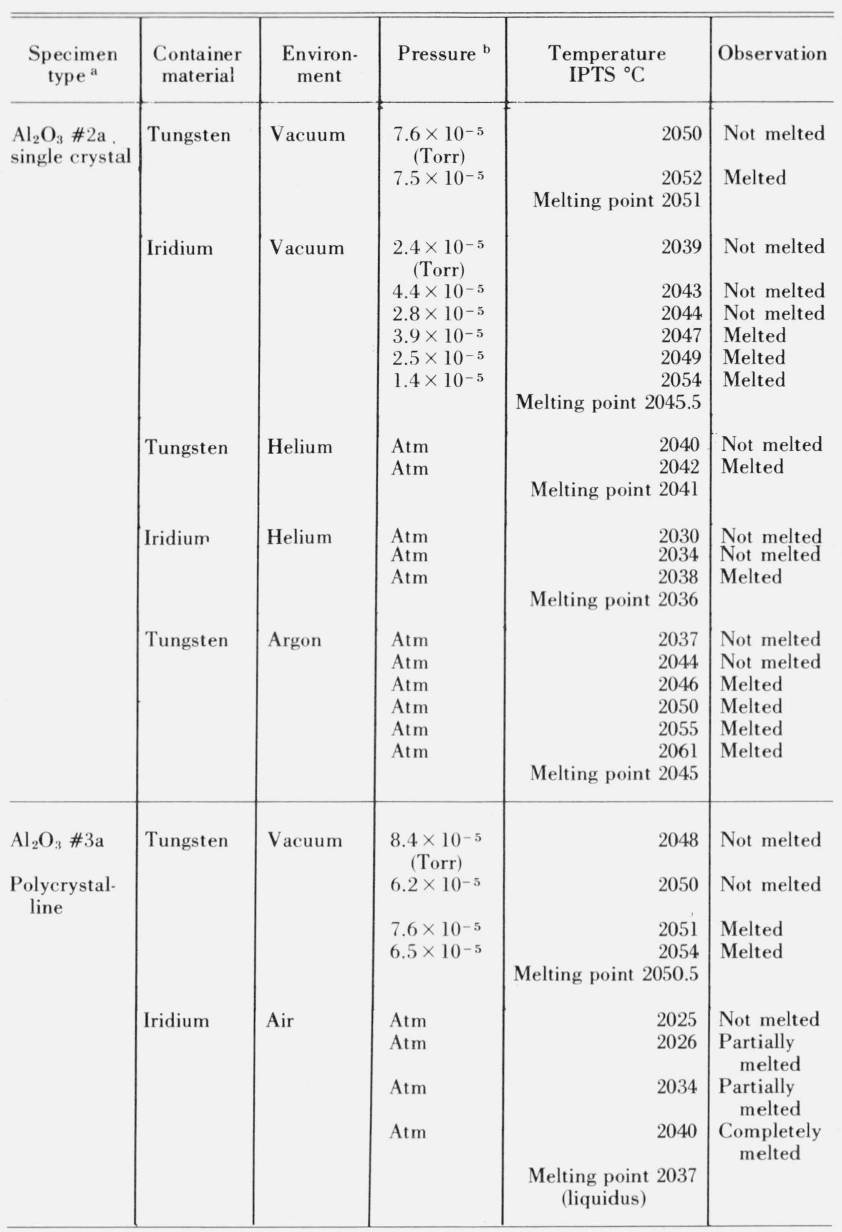

a Numerals (1, 2 or 3 ) indicate separate lots purchased at different times. Letters (a, b or c) represent individual samples selected from lots \#1, 2 , or 3 .

h The symbol atm roughly signifies atmospheric pressure.

TABLE 7. Summary of $\mathrm{Al}_{2} \mathrm{O}_{3}$ melting points

\begin{tabular}{|c|c|c|}
\hline Environment & $\begin{array}{l}\text { Tungsten } \\
\text { container }\end{array}$ & Iridium container \\
\hline $\begin{array}{l}\text { Vacuum } \\
\text { Argon }\end{array}$ & $\begin{array}{c}{ }^{\circ} \mathrm{C}, \text { IPTS } \\
2051 \\
2045\end{array}$ & $\begin{array}{c}{ }^{\circ} \mathrm{C}, \text { IPTS } \\
2046\end{array}$ \\
\hline $\begin{array}{l}\text { Helium } \\
\text { Air }\end{array}$ & 2041 & $\begin{array}{c}2036 \\
2038 \text { (liquidus) }\end{array}$ \\
\hline
\end{tabular}

It is difficult to assign exact limits of precision and accuracy to the melting point values. Each melting point was obtained through the use of an integral system of equipment and procedures and involves the personal judgment of the investigator. An estimate of the precision obtained by an intercomparison of the results for all possible conditions would not be appropriate because influencing factors differ in extent. In fact, one prime purpose of the investigation was to detect differences in melting temperature for varying experimental conditions. Considering only one specific set of data pertaining to a given container and environment, the precision can be relegated to the ability to distinguish one temperature from another. This measure of the precision is estimated to be less than $\pm 1.5{ }^{\circ} \mathrm{C}$ at the melting point of $\mathrm{Al}_{2} \mathrm{O}_{3}$.

Considering the estimated precision it is apparent that real differences exist between the melting points listed in table 7. As expected from previous discussions, the melting points of $\mathrm{Al}_{2} \mathrm{O}_{3}$ determined in vacuum utilizing tungsten or iridium containers are the higher values. Gaseous atmospheres yield lower melting points. It is impossible to ascribe exact causes to the lower melting temperatures because more than one process may be operative. Presumably the premelting phenomenon has greater significance than either container reaction or dissociation.

An environment of air affected the $\mathrm{Al}_{2} \mathrm{O}_{3}$ samples in a manner unlike the other gases or vacuum. Specimens in air appeared to melt over a range of temperatures whereas the $\mathrm{Al}_{2} \mathrm{O}_{3}$ under the other conditions exhibit sharp congruent type melting. Characteristically a ring of brownish-colored polycrystalline material formed on the outer surfaces of the $\mathrm{Al}_{2} \mathrm{O}_{3}$ single crystals when heated in air at temperatures higher than about $2020{ }^{\circ} \mathrm{C}$. Companion slumping and minor flow were also evident. As the temperature was increased, the ring appeared to move inward until no portion of the sample was identifiable as a single crystal. At still higher temperatures the sample became more translucent losing its brownish hue. Polycrystalline samples behave in a similar manner, forming the outer ring with partial slumping at first and eventually becoming clear of glasslike in appearance. Since incongruent melting was clearly indicated, tables 6 and 7 list the melting point as the liquidus temperature. The explanation for the different behavior in air as opposed to helium or argon environments is unclear. The presence of nitrogen or Ir oxide and Ir vapors may be contributing factors although there is no discernible evidence for this. Water vapor, of course, was shown to produce accelerated dissociation.

Melting points determined in the Ir crucible were lower than corresponding values obtained utilizing the tungsten containers. The $5{ }^{\circ} \mathrm{C}$ lower values conceivably could be caused by the difference in the degree of reaction between $\mathrm{Al}_{2} \mathrm{O}_{3}$ and $\mathrm{W}$ and between $\mathrm{Al}_{2} \mathrm{O}_{3}$ and $\mathrm{Ir}$. The phase equilibria study on each of these systems essentially discounted this theory although reaction still could account for part of the reduction. An alternate explanation concerns the effective emittance of the $\mathrm{Ir}$ blackbody. A $5{ }^{\circ} \mathrm{C}$ lowering would require the emittance to be about 0.978 instead of the 0.998 calculated value. If the reflectivity were largely specular rather than diffuse, a change in the emittance of this order of magnitude would be expected. DeVoss [15] gives relationships showing the effect reflectivity has on the quality of various configurations of tungsten blackbodies. Detailed reflectivity data would be required to make similar calculations for iridium enclosure and this unfortunately is not available. However, an indication 
that the reflectivity of iridium does change adversely upon heating is the fact that it fails to maintain a dull roughed surface.

Ideally the limits of accuracy of the experimental melting points should be established through a comparison with the absolute or true value, but this is an unknown quantity. Intercomparison with literature values would not be meaningful because of the diversity of samples, techniques, temperature scales and other factors. At present an estimate of the maximum uncertainties must be obtained from a consideration of the associated experimental errors. At present the melting point obtained in vacuum with the tungsten container, $2051{ }^{\circ} \mathrm{C}$, is considered to be that least influenced by extraneous factors and thus is the value which it is thought approaches closest to the true melting temperature of $\alpha-\mathrm{Al}_{2} \mathrm{O}_{3}$. It is doubtful that the various source of error (purity, pyrometer, blackbody, etc.) would be of the same sign. Even so, the overall maximum uncertainties of the $2051{ }^{\circ} \mathrm{C}$ melting point were estimated to be within $\pm 6{ }^{\circ} \mathrm{C}$.

The same limits of accuracy, $\pm 6{ }^{\circ} \mathrm{C}$, can be assigned to the other melting points determined in tungsten only if it is stipulated that they apply to $\mathrm{Al}_{2} \mathrm{O}_{3}$ changed in some manner due to the environment. If these melting points are compared with the true value, the limits of uncertainties must be increased.

A still wider range of possible errors must be placed on the melting points determined using the Ir containers because of doubts concerning the quality of the blackbody. For the value obtained in vacuum, $2046^{\circ} \mathrm{C}$, maximum experimental errors are estimated to be no more than $\pm 10^{\circ} \mathrm{C}$. Again, the limits of error associated with the helium and air melting points should be increased when comparing these values with the true melting point of $\alpha-\mathrm{Al}_{2} \mathrm{O}_{3}$. Similar to the tungsten experiments, the $\pm 10{ }^{\circ} \mathrm{C}$ limits apply to an altered $\mathrm{Al}_{2} \mathrm{O}_{3}$.

\section{7. $\mathrm{Al}_{2} \mathrm{O}_{3}$ as a Standard}

Proposals to establish the melting point of $\mathrm{Al}_{2} \mathrm{O}_{3}$ as a secondary temperature standard should be viewed with caution. The study conducted here showed conclusively that gas atmospheres have pronounced effects upon the observed melting point. Only investigations utilizing a vacuum environment yield a value which can be thought of as approaching the absolute melting point. Even the container material can significantly modify the results. These conclusions, however, also apply to materials other than $\mathrm{Al}_{2} \mathrm{O}_{3}$ as amply illustrated by the variations found for the Rh melting points.

It is probable that no material can be utilized as a universal standard suitable for even a majority of possible conditions. The presently accepted metal secondary reference standards should be reviewed and evaluated, perhaps placing more stringent limiting conditions on their use. In this context $\mathrm{Al}_{2} \mathrm{O}_{3}$ conceivably could be used as a reference material provided the environmental conditions are specified. A cooperative $\mathrm{Al}_{2} \mathrm{O}_{3}$ melting point program among several laboratories is needed to establish the full potentialities of $\mathrm{Al}_{2} \mathrm{O}_{3}$. To this end the Commission on High Temperature and Refractories, International Union of Pure and Applied Chemistry is sponsoring such a program. Until the results of this joint effort are available it is recommended that investigators refrain from indiscriminate use of $\mathrm{Al}_{2} \mathrm{O}_{3}$ for references purposes and give consideration to environmental conditions.

Many thanks are due to E. M. Levin for the petrographic analyses and to A. L. Dragoo for preparation of the arc-image samples.

\section{References}

[1] H. F. Stimson, J. Res. NBS 65A (Phys. and Chem.) No. 3, 139-149 (1961).

[2] H. T. Wensel and W. F. Roeser, BS J. Research 5, 1309-1318 (1930). RP 258.

[3] W. F. Roeser and H. T. Wensel, BS J. Res. 12, 519-526 (1934). RP 676.

[4] W. F. Roeser, F. R. Caldwell, and H. T. Wensel, BS J. Res. 6, 1119-1129 (1931). RP 326.

[5] F. Henning and H. T. Wensel, BS J. Res. 10, 809-827 (1933). RP568.

[6] S. J. Schneider, NBS Mono. 68, 31 pp. (1963).

[7] P. D. Foote, C. O. Fairchild, and T. R. Harrison, Tech. Papers B. S. No. 170 14, 1-325 (1921).

[8] S. J. Schneider and C. L. McDaniel, Rev. Hautes Tempér. et Réfract. 3, 351-61 (1966).

[9] C. W. Kanolt, Bull. B. S. 10, 295-3í3 (1914).

[10] S. J. Schneider, J. Am. Ceram. Soc. 43, 354-355 (1963).

[11] H. N. Frock and W. T. Shreve, Instrum. Soc. Amer. Preprint No. 29.5. 1963, 1-6 (1963).

[12] R. D. Lee, Metrologia 2 [4], 150-162 (1966).

[13] J. J. Diamond and A. L. Dragoo, Rev. Hautes Tempér. et Réfract. 3, 273-279 (1966).

[14] A. Gouffé, Rev. Opt. 24, 1-10 (1945).

[15] J. C. DeVoss, Physica 20, 669-689 (1954).

[16] W. Gutt, J. Sci. Instrum. 41, 393-394 (1964).

[17] R. L. Weber, Heat and Temperature Measurement, 400-406 (Prentice-Hall Inc., New York, 1950).

[18] A. G. Worthing, J. Applied Phys. 11, 421-437 (1940).

[19] J. C. DeVoss, Physica 20, 690-714 (1954).

[20] H. J. Kostkowski and R. D. Lee, NBS Mono. 41, 28 pp. (1962),

[21] M. Hansen, Constitution of Binary Alloys, 2d edition, 1305 pp. (McGraw-Hill Book Co., New York, N.Y., 1958).

[22] R. P. Elliott, Constitution of Binary Alloys, lst Supplement, 877 pp. (McGraw-Hill Book Co., New York, N.Y., 1965).

[23] K. Motzfeldt and G. Gitlesen, private communication (1965).

[24.] M. Hoch and H. L. Johnston, J. Am. Chem. Soc. 76, 2560-2561 (1954).

[25] J. Drowart, G. DeMaria, R. P. Burns, and M. G. Inghram, J. Chem. Physics 32, 1366-1372 (1960).

[26] L. N. Grossman, Bull. Am. Ceram. Soc. 45, 371 (1966) (Abstract); preprint, High Temperature Thermal Analysis of Ceramic Systems.

[27] A. R. Ubbelohde, Melting and Crystal Structure, pp. 218-242 (Clarendon Press, Oxford, 1965).

[28] L. S. Darken and R. W. Gurry, Physical Chemistry of Metals, pp. 90-92 (McGraw-Hill Book C.o., New York, N.Y., 1953).

[29] G. Gitlesen and K. Motzfeldt, Acta Chem. Scand. 19, 661-669 (1965),

[30] A. L. Kozlovskii and K. S. Shlyakova, Tr. Vses. Nauch.-Issled. Inst. Autogen Obrabotki Metal. 6, 136-139 (1960); Chem. Abstr. 55, 16062 (1961).

[31] P. B. Kantor, L. S. Lazareva, V. V. Kandyba, and E. M. Fomichov, Ukr. Fiz. Zh. 7, 205 (1962).

[32] D. J. Barber and N. J. Tighe, J. Res. NBS 69A (Phys. and Chem.) No. 3, 271-280 (1965).

[33] O. Ruff and O. Goecke, Z. Angew. Chem. 24, 1459-1465 (1911).

[34] O. Ruff, Z. Anorg. Allgem. Chem. 82,373-400 (1913). 
[35] E. Tiede and E. Birnbrauer, Z. Anorg. Chem. 87, 129-168 (1914).

[36] O. Ruff and G. Lauschke, Z. Anorg. Chem. 97, 73-113 (1916).

[37] H. v. Wartenberg, H. Linde, and R. Jung, Z. Anorg. Allgem. Chem. 176, 349-362 (1928).

[38] E. N. Bunting, J. Res. NBS 6, 947-949 (1931) RP317.

[39] O. Weigel and F. Kaysser, Neues Jahrb. Mineral Geol. 64, 321-396 (1931).

[40] R. F. Geller and E. N. Bunting, J. Res. NBS 31, 255-270 (1943) RP1564.

[41] R. F. Geller and P. J. Yavorsky, J. Res. NBS 34, 395-401 (1945) RP1649.

[42] W. A. Lambertson and F. H. Gunzel, Jr., A.N.L., U.S. AEC Publ. AECD-3465, 1-4 (1952).

[43] S. M. Lang. F. P. Knudsen, C. L. Filmore, and R. S. Roth, NBS Circ. 568, 1-32 (1956).

[44] F. H. Aldred and H. E. S. White, Trans. Brit. Ceram. Soc. 58 , 199-223 (1959).

[45] S. D. Mark, Jr., J. Am. Ceram. Soc. 42, 208 (1959).
[46] J. J. Diamond and S. J. Schneider, J. Am. Ceram. Soc. 43, $1-3(1960)$

[47] R. N. McNally, F. I. Peters, and P. H. Ribbe, J. Am. Ceram. Soc. 44, 491-493 (1961).

[48] V. Ya. Chekhovskoi and V. A. Petrov, Meas. Tech. 9, 751-753 (1963) [English translation]; original article-Izmeritel'naya Teknika 9, 26-28 (1963).

[49] W. Gutt, J. Sci. Instrum. 41, 393-394 (1964).

[50] B. Riley, J. Sci. Instrum. 41, 504-505 (1964).

[51] M. Foex, Solar Energy 9, 61-67 (1965).

[52] P. B. Kantor, E. N. Fomichev, and V. V. Kandyba, Izmeritel'n. Tekhn. 5, 27-29(1966).

[53] T. Sata, Rev. Hautes Tempér. et Réfract. 3, 337-341 (1966).

[54] G. Urbain and M. Rouannet, Rev. Hautes Temér. et Réfract. 3, 363-369 (1966).

[55] G. K. Burgess, BS J. Res. 1, 635-640 (1928).

[56] Chemical Abstracts 65, 11371(d), (1966).

(Paper 71A4-463) 